\title{
Nitrogen fertilization affects maize grain yield through regulating nitrogen uptake, radiation and water use efficiency, photosynthesis and root distribution
}

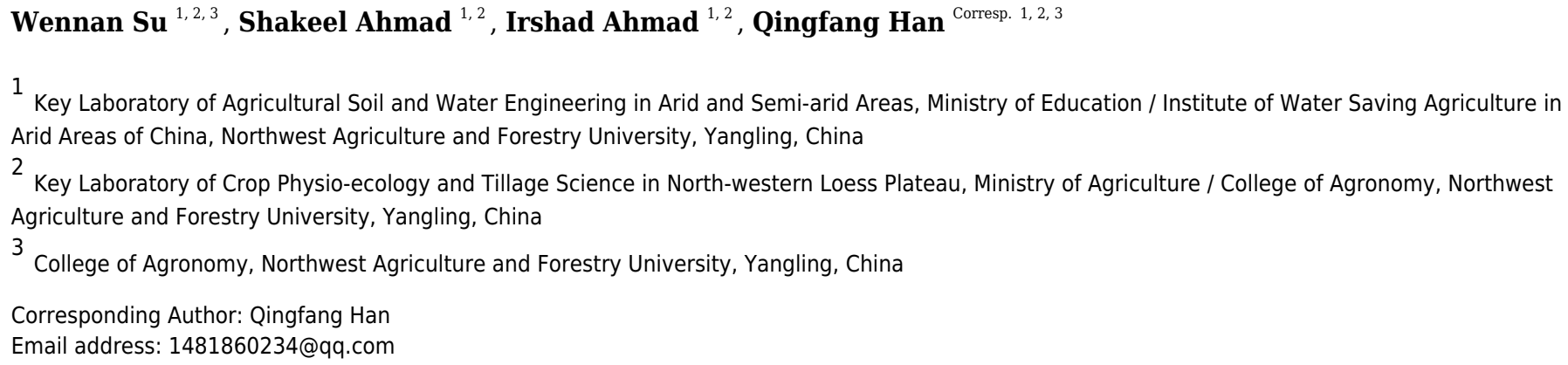

High external nitrogen $(\mathrm{N})$ inputs can maximize maize yield but can cause a subsequent reduction in $\mathrm{N}$ use efficiency (NUE). Thus, it is necessary to identify the minimum effective $\mathrm{N}$ fertilizer input that does not affect maize grain yield (GY) and to investigate the photosynthetic and root system consequences of this optimal dose. We conducted a 4-year field experiment from 2014 to 2017 with four $N$ application rates: $300\left(N_{300}\right), 225\left(N_{225}\right), 150$ $\left(\mathrm{N}_{150}\right)$, and $0 \mathrm{~kg} \mathrm{ha}^{-1}\left(\mathrm{~N}_{0}\right)$ in the Northwest of China. GY was assessed by measuring the photosynthetic capacity and root system (root volume, surface area, length density and distribution). Grain yield decreased by $-3 \%, 7.7 \%$, and $21.9 \%$ when the N application rates decreased by $25 \%, 50 \%$, and $100 \%$ from $300 \mathrm{~kg} \mathrm{ha}^{-1}$. We found that yield reduction driven by $\mathrm{N}$ reduction was primarily due to decreased radiation use efficiency (RUE) and WUE instead of intercepted photosynthetically active radiation and evapotranspiration. In the $\mathrm{N}_{225}$ treatment, GY, WUE, and RUE were not significantly reduced, or in some cases, were greater than those of the $\mathrm{N}_{300}$ treatment. This pattern was also observed with relevant photosynthetic and root attributes (i.e., high net photosynthetic rate, stomatal conductance, and root weight, as well as deep root distribution). Our results suggest that application of $\mathrm{N}$ at $225 \mathrm{~kg} \mathrm{ha}^{-1}$ can increased yield by improving the RUE, WUE, and NUE in semi-arid regions. 


\section{Nitrogen fertilization affects maize grain yield through}

3 regulating nitrogen uptake, radiation and water use

4 efficiency, photosynthesis and root distribution

6

Wennan Su 1,2,3, Shakeel Ahmad ${ }^{2,3}$, Irshad Ahmad ${ }^{2,3}$, and Qingfang Han 1,2,3*

1College of Agronomy, Northwest Agriculture and Forestry University

2Key Laboratory of Crop Physio-ecology and Tillage Science in North-western Loess Plateau, Ministry of Agriculture / College of Agronomy,

Northwest Agriculture and Forestry University

3Key Laboratory of Agricultural Soil and Water Engineering in Arid and Semi-arid Areas, Ministry of Education / Institute of Water Saving

Agriculture in Arid Areas of China, Northwest Agriculture and Forestry University

14 Corresponding Author:

15 Qingfang $\operatorname{Han}^{1,2,3}$

16 Yangling, Shaanxi, China

17 Email address: 1481860234@qq.com 
18

19

20

21

22

23

24

25

26

27

28

29

30

31

32

33

34

35

36

37

38

39

40

41

42

43

44

45

46

47

48

49

50

51

52

53

54

55

56

57

\section{Abstract}

High external nitrogen $(\mathrm{N})$ inputs can maximize maize yield but can cause a subsequent reduction in $\mathrm{N}$ use efficiency (NUE). Thus, it is necessary to identify the minimum effective $\mathrm{N}$ fertilizer input that does not affect maize grain yield (GY) and to investigate the photosynthetic and root system consequences of this optimal dose. We conducted a 4-year field experiment from 2014 to 2017 with four $\mathrm{N}$ application rates: $300\left(\mathrm{~N}_{300}\right), 225\left(\mathrm{~N}_{225}\right), 150\left(\mathrm{~N}_{150}\right)$, and $0 \mathrm{~kg}$ $\mathrm{ha}^{-1}\left(\mathrm{~N}_{0}\right)$ in the Northwest of China. GY was assessed by measuring the photosynthetic capacity and root system (root volume, surface area, length density and distribution). Grain yield decreased by $-3 \%, 7.7 \%$, and $21.9 \%$ when the $\mathrm{N}$ application rates decreased by $25 \%, 50 \%$, and $100 \%$ from $300 \mathrm{~kg} \mathrm{ha}^{-1}$. We found that yield reduction driven by $\mathrm{N}$ reduction was primarily due to decreased radiation use efficiency (RUE) and WUE instead of intercepted photosynthetically active radiation and evapotranspiration. In the $\mathrm{N}_{225}$ treatment, GY, WUE, and RUE were not significantly reduced, or in some cases, were greater than those of the $\mathrm{N}_{300}$ treatment. This pattern was also observed with relevant photosynthetic and root attributes (i.e., high net photosynthetic rate, stomatal conductance, and root weight, as well as deep root distribution). Our results suggest that application of $\mathrm{N}$ at $225 \mathrm{~kg} \mathrm{ha}^{-1}$ can increased yield by improving the RUE, WUE, and NUE in semi-arid regions.

\section{Introduction}

In the past four decades, global maize production has greatly increased (FAO, 2018) mainly due to application of nitrogen $(\mathrm{N})$ fertilizers. Worldwide, $\mathrm{N}$ fertilizer has widely been excessively applied to achieve higher grain yields (Cui et al., 2009; Meng et al., 2016; Liang et al., 2020).

For example, the average dose of $\mathrm{N}$ fertilizer applied by the farmers was greater than $300 \mathrm{~kg} \mathrm{ha}^{-1}$ $\left(288 \pm 113 \mathrm{~kg} \mathrm{ha}^{-1}\right)$, which far exceeds the optimal $\mathrm{N}$ rates for maize demonstrated in field experiments (Zhang et al., 2015a; Chang et al., 2014; Yang et al., 2017). $\mathrm{N}$ fertilizer was applied in excess (350-600 $\mathrm{kg} \mathrm{ha}^{-1}$ year $^{-1}$, Mueller et al., 2013) in an attempt to maximize yields in the North China Plain. However, excessive application of $\mathrm{N}$ fertilizer has negative effects on crops, greatly reduces $\mathrm{N}$ use efficiency (NUE), and causes significant nitrate leaching losses (more than $50 \% \mathrm{~N}$ to the environment) and contamination of groundwater (Erisman et al., 2013; Wang et al.,2014; McBratney and Field, 2015; Ahmad et al., 2018; Suchy et al., 2018; Wang et al., 2019). Reducing N input rates from this level to "moderate" levels in maize fields may improve NUE, maintain a fair level of maize grain yield (Zhao et al. 2010; Dai et al., 2015, Qiang et al., 2019), and display less negative environmental impacts. In order to implement reduced $\mathrm{N}$ input rates, it is necessary to assess the extent to which the $\mathrm{N}$ fertilizer application rate is consistent with crop $\mathrm{N}$ requirements to maximize resource utilization and maintain relatively high grain yields (Robertson and Vitousek, 2009; Zhang et al., 2015b).

Radiation interception and radiation use efficiency (RUE) form the basic framework for analyzing crop yield constraints. Variations in crop biomass due to abiotic factors may be attributed to intercepted photosynthetically active radiation (IPAR), RUE, or the combination of both IPAR and RUE (Fletcher et al., 2013). Reduced leaf area under low-N conditions is accompanied by a reduction in radiation interception (Massignam et al., 2012). Low-N 
58

59

60

61

62

63

64

65

66

67

68

69

70

71

72

73

74

75

76

77

78

79

80

81

82

83

84

85

86

87

88

89

90

91

92

93

94

95

96

97

conditions primarily decrease the photosynthetic rate per unit area (Vos, Van Der Putten and Birch, 2005), indicating that a low $\mathrm{N}$ effect on both leaf size and photosynthetic capacity may affect the final grain yield. Understanding how maize production and resource use are affected by varying $\mathrm{N}$ application rates will inform improvement of $\mathrm{N}$ fertilizer management to achieve optimal grain yield and resource use efficiency. The appropriate amount of $\mathrm{N}$ fertilizer input can improve utilization of precipitation during the crop season (Dai et al., 2015; Herrera et al., 2016; Yang et al., 2017; Qiang et al., 2019). Previous studies of the effect of $\mathrm{N}$ fertigation on grain yield and resource use efficiency primarily describe the effects of single resource utilization at the leaf or plant level (Brown, Jamieson and Moot, 2012). A preceding study described the relationship between maize water use efficiency (WUE) and NUE in pot conditions (Wang et al., 2019). However, few comprehensive studies on the effects of $\mathrm{N}$ fertilizer on the utilization of radiation, water, and $\mathrm{N}$ resources in field crops have been performed.

Enhancing photosynthesis is critical to promoting crop yield (Mu et al., 2017). In order to understand the underlying mechanisms and differences in photosynthetic capacity, it is necessary to determine the relevant photosynthetic parameters of ear leaves (Li et al., 2013; Zhang et al., 2017; Lamptey et al., 2017). Root morphology and distribution also play key roles in the acquisition of soil resources such as nutrients and water (Ristova and Busch, 2014; Lynch, 2013; Yu et al., 2014). Mi et al. (2010) proposed the ideotype root architecture of "high yield and high $\mathrm{N}$ efficiency" in maize, which provided references for root research. In field conditions, the complexity of root sampling has limited efforts to understand the effects of $\mathrm{N}$ on roots to shoots. Such research has been conducted under pot conditions (Wang et al., 2019); thus, it is not possible to assess variation due to differences in light and temperature conditions as well as nitrate $\mathrm{N}$ leaching, as occurs in field conditions. Limited knowledge about shoot and root traits related to maize grain yield, NUE, RUE, and WUE under field conditions was investigated. Therefore, exploring the response of photosynthetic parameters and root development to grain yield reduction due to $\mathrm{N}$ reduction will provide an important reference for management of $\mathrm{N}$ fertilizer inputs.

In the current study, we determined that $\mathrm{N}$ reduction results in maintenance of photosynthetic activity and root development to maximize grain yield and radiation, water, and $\mathrm{N}$ use by maize crops. The objectives of this study were to 1 ) investigate the effects of $\mathrm{N}$ reduction on water, radiation, and $\mathrm{N}$ use efficiencies in maize crops, and 2) determine the effects of $\mathrm{N}$ reduction on photosynthetic activity and root development in maize crops under semi-arid conditions. Our findings provide key data to support enhanced maize production and resource use efficiency.

\section{Materials and Methods} Field experiments

A 4-year field experiment was conducted on the same land at the agricultural experimental station of Northwest A\&F University in Yangling $\left(34^{\circ} 20^{\prime} \mathrm{N}, 108^{\circ} 04^{\prime} \mathrm{E}\right.$, elevation, $\left.455 \mathrm{~m}\right)$, Shaanxi province, China in 2014, 2015, 2016, and 2017. The experimental site experienced an annual average daylight of $2150 \mathrm{~h}$, an annual average temperature of $12^{\circ} \mathrm{C}$ to $14^{\circ} \mathrm{C}$, and an average annual precipitation of $581 \mathrm{~mm}$. The annual mean temperature and total precipitation of 
the experimental area are shown in Fig. 1. The soil of the experimental site is classified as a dark loess soil, and the former crop was winter wheat. Before sowing, soil chemical properties were analyzed in the top $60 \mathrm{~cm}$ of soil for organic matter content, $\mathrm{N}$, phosphorus $(\mathrm{P})$, and potassium (K) (Table 1).

The research work was carried out with a randomized complete block design with three replications. The total sub plot size was $39 \mathrm{~m}^{2}$ ( $7.8 \mathrm{~m}$ long and $5 \mathrm{~m}$ wide). The row-to-row spacing was maintained at $60 \mathrm{~cm}$ and plant-to-plant spacing at $25 \mathrm{~cm}$. The maize seeds were planted manually, and in each hill, two seeds were sown at a depth of $5 \mathrm{~cm}$ in the middle of June during each growing season. Plants were thinned manually for normal plant population densities in the area of (67,500 pl. ha) at V3 (three-leaf stage) (Ritchie and Hanway, 1982). Plots were kept free of weeds, insects, and diseases; and the weeding was controlled by hand and hoe during each growing season. The $\mathrm{N}$ treatments applied in this study were: 1) no $\mathrm{N}\left(\mathrm{N}_{0}, 100 \%\right.$ reduction from $\left.\mathrm{N}_{300}\right)$; 2) $150 \mathrm{~kg} \mathrm{~N} \mathrm{ha}^{-1}\left(\mathrm{~N}_{150}, 50 \%\right.$ reduction from $\left.\mathrm{N}_{300}\right)$; 3) $225 \mathrm{~kg} \mathrm{~N} \mathrm{ha}^{-1}\left(\mathrm{~N}_{225}, 25 \%\right.$ reduction from $\left.\mathrm{N}_{300}\right)$; and 4) $300 \mathrm{~kg} \mathrm{~N} \mathrm{ha}^{-1}\left(\mathrm{~N}_{300}\right.$, the traditional $\mathrm{N}$ dose applied by farmers in the Loess Plateau of China). Fertilizer $\mathrm{N}$ was sourced from urea $(46 \% \mathrm{~N})$, evenly split in the fractions of $1 / 2$ at pre-sowing and side-banded deep $(5 \mathrm{~cm})$ into the soil on the sowing rows of $1 / 2$ at the twelve-leaf stage. A total of $150 \mathrm{~kg}$ of phosphorus (calcium superphosphate, $\mathrm{P}_{2} \mathrm{O}_{5}$ $16 \%) \mathrm{ha}^{-1}$ and $150 \mathrm{~kg}$ of potassium (as potassium sulfate, $\mathrm{K}_{2} \mathrm{O} 45 \%$ ) ha ${ }^{-1}$ were applied 5 days before sowing. Irrigation was applied at the twelve-leaf stage $(75 \mathrm{~mm})$. The amount of irrigation was controlled by a water meter (Zhejiang Ningbo Water Meter Co., Ltd.).

\section{Sampling and measurements}

\section{Intercepted Photosynthetically Active Radiation (IPAR)}

During the V6-R3, IPAR was measured every 5-7 days (on clear and sunny days between 11:00 AM to 2:00 PM) using a SunScan Canopy Analyzer (Delta, UK). In each plot, three points were chosen. When measuring, the line sensor was placed horizontally between the two ridges $(5 \mathrm{~cm}$ from the soil surface) and was used to collect three consecutive readings of transmitted photosynthetically active radiation (Chen et al., 2016). Round-trip observations were used to minimize error.

\section{Soil Water Content}

At sowing and maturity, soil water content from the $0-200 \mathrm{~cm}$ layer was determined using a hand-held soil iron drill (Zhang et al., 2019). Between 0 and $20 \mathrm{~cm}$, samples were collected every $10 \mathrm{~cm}$, and between 20 and $200 \mathrm{~cm}$, samples were collected every $20 \mathrm{~cm}$. Soil samples were stored in a closed aluminum box and weighed before drying, oven-dried at $105^{\circ} \mathrm{C}$ for $24 \mathrm{~h}$, and weighed separately. The soil water content of each plot was calculated from the average of three random soil core samples. The soil water content was calculated as the difference between the fresh soil weight minus the dry soil weight divided by the dry soil weight.

\section{Photosynthetic Parameters and Leaf Area Index (LAI)}

In 2016 and 2017, 20 plants were marked prior to the eight-leaf stage (V8). At V8, the tasseling stage (VT), milking stage (R3), and physiological maturity (R6), the three marked plants per plot were selected to measure the net photosynthetic rate $(\mathrm{Pn})$, intercellular $\mathrm{CO}_{2}$ concentration $(\mathrm{Ci})$, 
138

139

140

141

142

143

144

145

146

147

148

149

150

151

152

153

154

155

156

157

158

159

160

161

162

163

164

165

166

167

168

169

170

171

172

173

and stomatal conductance (Gs) on the ear leaves (at VT, R3, and R6) or fully expanded leaves at the top of a plant (at V8) using a photosynthesis analyzer system (LI-6400, LI-COR, Lincoln, Nebraska, USA) on a clear sunny day between 9:00 AM to 11:00 AM (Zhang et al., 2017). The same plants were used for measuring the green leaf area at V8, VT, R3, and R6. The green leaf area index (LAI) was calculated as follows (Birch, Vos and Van Der Putten, 2003):

LAI $=0.75 \times$ Leaf length $\times$ maximum width $\times$ number of plants within a unit area of land /area of land

\section{Root System}

Three plants root were sampled using the soil profile method (Holanda et al., 1998) at the V8, VT, R3, and R6 stages of maize. Each root system was excavated from an area of $0.15 \mathrm{~m}^{2}$ (line spacing $0.6 \mathrm{~m} \times$ row spacing $0.25 \mathrm{~m}$ ) soil around the center of the plant. Root sampling was conducted at depth intervals of $0-30 \mathrm{~cm}$ (surface soil layer), 30-60 cm (middle soil layer), and 60-90 cm (deep soil layer) in each plot. Excavated roots were immersed overnight in a plastic container filled with water and washed with tap water on a $0.25-\mathrm{mm}$ screen until the roots were free of soil. Roots were scanned using an HP Scanjet 8200 scanner, and each root image was analyzed using a root analysis program (Regent Instruments Inc. WinRhizo Provision 5.0, Canada) to obtain the root surface area $\left(\mathrm{cm}^{2}\right.$ plant $\left.{ }^{-1}\right)$ and root length $(\mathrm{mm})$. Root volume was measured by the drainage method. Root length density was calculated as the average of three plants' root lengths divided by the soil volume ( $\mathrm{Li}$ et al., 2010). Root samples were dried for $48 \mathrm{~h}$ at $70^{\circ} \mathrm{C}$ in an oven to obtain the root dry weight per plant.

\section{Biomass Yield, Shoot N Content, and Grain Yield}

Four central rows were harvested randomly at $20 \mathrm{~m}^{2}$ to measure the grain yield at harvest in each plot. Ten ears were randomly selected from each plot and threshed separately to determine moisture content and kernel number. Grain yield was estimated based on kernel weight and water content and expressed as $14 \%(\mathrm{w} / \mathrm{w})$ moisture content. Six plants were sampled at each plot and were divided into leaves, stems, and grains. Before determining the $\mathrm{N}$ concentration, all plant parts were dried at $70^{\circ} \mathrm{C}$ for $48 \mathrm{~h}$ and weighed. After weighing, the samples were ground into powder using a willey-type mill $(<1 \mathrm{~mm}$ mesh), weighed $(0.3-0.4 \mathrm{~g})$, and were mineralized using $\mathrm{H}_{2} \mathrm{SO}_{4}-\mathrm{H}_{2} \mathrm{O}_{2}$; then, total $\mathrm{N}$ concentration was obtained by using an automatic Kjeldhal microdistillation analyzer (FOSS, Sweden, Nelson and Sommers, 1973).

\section{Statistical analysis}

Daily intercepted solar radiation was calculated using the following equation (Liu et al., 2014):

$\mathrm{LT}=\frac{P A R_{L}}{P A R_{T}}$

Where $\mathrm{LT}$ is the light transmission ratio, $\mathrm{PAR}_{\mathrm{L}}$ is the intercepted photosynthetically active radiation at the bottom of the canopy, and $\mathrm{PAR}_{\mathrm{T}}$ is the intercepted photosynthetically active radiation at the top of the canopy. 
174

175

176

177

178

179

180

181

182

183

184

185

186

187

188

189

190

191

192

193

194

195

196

197

198

199

200

201

202

203

204

205

206

207

208

209

The measured intercepted photosynthetically active radiation value of the bottom layer was analyzed by two-dimensional interpolation over 1 day to obtain the intercepted photosynthetically active radiation of the entire canopy. Then, the intercepted photosynthetically active radiation rate obtained by interpolation analysis is multiplied by the incident PAR measured on the corresponding date by the meteorological observatory to determine the amount of canopy IPAR.

Radiation use efficiency (RUE) was calculated using the following equation:

$R U E=\frac{M h}{\sum Q} \times 10^{-7} \times 100 \%$

Where $\sum \mathrm{Q}\left(\mathrm{MJ} \mathrm{m}^{-2}\right)$ is the accumulated intercepted solar radiation, $\mathrm{h}\left(\mathrm{kJ} \mathrm{kg}^{-1}\right)$ is the heat energy released of per $\mathrm{kg}$ of grain yield, and $\mathrm{M}$ is the grain yield $\left(\mathrm{kg} \mathrm{ha}^{-1}\right)$.

Water use efficiency (WUE) was calculated as:

$\mathrm{WUE}=\frac{G Y}{E T}$

Where GY $\left(\mathrm{kg} \mathrm{ha}^{-1}\right)$ is the grain yield, and ET $(\mathrm{mm})$ is the evapotranspiration, as calculated as by soil water balance equation (Huang et al., 2005).

The following equations were also used:

Internal $\mathrm{N}$ efficiency, INE $=\frac{G Y}{S N C}$

Agronomic $\mathrm{N}$ use efficiency, ANE $=\frac{\left(G Y_{N i}-G Y_{N 0}\right)}{N i}$

Apparent $\mathrm{N}$ recovery efficiency, REN $(\%)=\frac{\left(S N C_{N i}-S N C_{N 0}\right)}{N i} \times 100$

$\mathrm{N}$ harvest index, NHI $(\%)=\frac{G N C}{S N C} \times 100$

where SNC $\left(\mathrm{kg} \mathrm{ha}^{-1}\right)$ is the shoot $\mathrm{N}$ content calculated as biomass $\left(\mathrm{kg} \mathrm{ha}^{-1}\right)$ multiplied by shoot $\mathrm{N}$ concentration $\left(\mathrm{kg} \mathrm{kg}^{-1}\right), \mathrm{i}\left(\mathrm{N}\right.$ rates, $\left.\mathrm{kg} \mathrm{ha}^{-1}\right)$ is $\mathrm{N}$ application rates 150,225 , or $300, \mathrm{GY}_{\mathrm{Ni}}(\mathrm{kg}$ $\left.\mathrm{ha}^{-1}\right)$ is grain yield in the $\mathrm{N}$ application plots, $\mathrm{GY}_{\mathrm{N} 0}\left(\mathrm{~kg} \mathrm{ha}^{-1}\right)$ is grain yield in the no-N application plots, and $\mathrm{Ni}$ is the $\mathrm{N}$ application rate. $\mathrm{SNC}_{\mathrm{Ni}}\left(\mathrm{kg} \mathrm{ha}^{-1}\right)$ is the shoot $\mathrm{N}$ content in $\mathrm{N}$ application plots, $\mathrm{SNC}_{\mathrm{N} 0}\left(\mathrm{~kg} \mathrm{ha}^{-1}\right)$ is the shoot $\mathrm{N}$ content in the no-N application plots. GNC is grain $\mathrm{N}$ content $\left(\mathrm{kg} \mathrm{ha}^{-1}\right)$.

The experimental data were organized and processed using Microsoft and are presented with standard error. SPSS18.0 (SPSS Institute Inc.) statistical analysis software was used for variance analysis. The data was checked for normality (Kolmogorov-Smirnov test) and homogeneity of variance (Bartlett-Box test). The effects of $\mathrm{N}$ rates, years, and their interactions on the measured variables were tested using one- and two-way ANOVAs. To identify significant treatments effects, multiple comparisons among different treatments were performed using Duncan's multiple range test. Differences with $P<0.05$ were considered statistically significant.

\section{Results}

\section{Grain yield, Biomass Yield, and Crop Resource Utilization}

Our results revealed that the year and $\mathrm{N}$ application rates showed significant effects on grain yield (GY), biomass yield (BY), grain N content (GNC), agronomic $\mathrm{N}$ use efficiency (ANE), 
210 apparent $\mathrm{N}$ recovery efficiency (REN), and $\mathrm{N}$ harvest index (NHI) (Table 2). The interaction 211 between $\mathrm{N}$ application rate and year had no significant effect on the above parameters. We 212 observed no significant differences in GY, BY, and GNC between $\mathrm{N}_{225}$ and $\mathrm{N}_{300}$ in all growing

213 seasons. Compared with $\mathrm{N}_{300}$, the $\mathrm{GY}$ of $\mathrm{N}_{150}$ and $\mathrm{N}_{0}$ decreased ranging from $4.7 \%$ to $13.6 \%$ and $21419.7 \%$ to $22.8 \%$, respectively, while the grain yield of treatment $\mathrm{N}_{225}$ increased ranging from $2151.5 \%$ to $3.7 \%$ averaged of four years. Treatment $\mathrm{N}_{300}$ increased biomass yield ranging from $28 \%$ 216 to $34 \%$, compared with $\mathrm{N}_{0}$, while $\mathrm{N}_{225}$ increased biomass yield ranging from $27 \%$ to $32 \%$ in the 217 four years. The GY difference among years may be due to the rainfall amount and seasonal 218 distribution. Rainfall was $390 \mathrm{~mm}, 284 \mathrm{~mm}, 311 \mathrm{~mm}$, and $371 \mathrm{~mm}$ in 2014, 2015, 2016, and 219 2017, respectively (Fig. 1). Among the experimental years, GY was higher in 2016 and 2017 220 compared to 2014 and 2015. 2017 was a more suitable year for maize growth. Although the 221 rainfall in 2016 was reduced, the distribution was relatively uniform throughout the growth

222

223

224

225

226

227

228

229

230

231

232

233

234

235

236

237

238

239

240

241

242

243

244

245

246

247

248

249

period. The early rainfall ensured the regularity and vegetative growth of maize seedlings. The lower GY in 2015 can be explained by the reduced rainfall. In 2014, the greater rainfall was mainly due to the large amount of rainfall occurring 70 days after sowing. Continuous rainfall from the silking to the flowering stage affected maize pollination, and severe stalk rot disease occurred during the grain filling stage, which caused pro-senescence (Fig. 1), causing lower GY. The optimal rate of $\mathrm{N}$ application increased the AEN, REN, and NHI, except for the AEN of $\mathrm{N}_{150}$ during the 2016 growing season. The NHI was highest for the $\mathrm{N}_{225}$ and $\mathrm{N}_{150}(2014,2015$, and 2017) or $\mathrm{N}_{225}$ (2016) treatments.

Throughout the crop growth cycle, differences in ET among $\mathrm{N}$ treatments were significant $(P<0.05$, Table 3). During growing seasons 2015, 2016, and 2017, we observed that the rate of $\mathrm{N}$ application showed no significant effect on IPAR. The IPAR of $\mathrm{N}_{0}$ was less than that of $\mathrm{N}_{300}$ in the 2014 growing season. SNC was increased by increasing the $\mathrm{N}$ application rate. For $\mathrm{N}_{300}$, SNC increased ranging from $73 \%$ to $92 \%$ compared with $\mathrm{N}_{0}$, and $\mathrm{N}_{225}$ application increased SNC ranging from $68 \%$ to $81 \%$ compared with the $\mathrm{N}_{0}$ treatment in the four years. IEN was increased with a low rate $\mathrm{N}$ application. Application of $\mathrm{N}$ at $225 \mathrm{~kg} \mathrm{ha}^{-1}$ increased IEN ranging from $8.5 \%$ to $12.3 \%$ compared with $\mathrm{N}_{300}$, while $\mathrm{N}_{150}$ decreased IEN ranging from $9.7 \%$ to $20.7 \%$ compared with $\mathrm{N}_{300}$ in the four years. $\mathrm{N}$ application at the $\mathrm{N}_{300}$ and $\mathrm{N}_{225}$ rates were similar, while $\mathrm{N}_{300}$ increased RUE ranging from $19 \%$ to $26 \%$, whereas $\mathrm{N}_{225}$ increased RUE ranging from $23 \%$ to $29 \%$ compared with $\mathrm{N}_{0}$ in the four years. Reduced $\mathrm{N}$ application was associated with reduced WUE. Our results showed that $\mathrm{N}_{225}$ increased grain WUE ranging from $25 \%$ to $26 \%$ compared to $\mathrm{N}_{0}$ in the four years. WUE was also significantly increased in the $\mathrm{N}_{300}$ treatment but to a lesser extent (19\%-22\%). RUE and NUE exhibited non-linear responses to the $\mathrm{N}$ application rate, indicating that the maximum grain yield can occur with $\mathrm{N}_{150}$ or $\mathrm{N}_{225}$ treatments. The differential grain yield between $\mathrm{N}_{225}$ and $\mathrm{N}_{300}$ was relatively small.

\section{Photosynthetic parameters and LAI}

$\mathrm{N}$ application rates and year had significant effects on $\mathrm{Pn}, \mathrm{Gs}$, and $\mathrm{Ci}$, but the interaction between $\mathrm{N}$ application rates and year did not display significant correlated (Fig. 2). In both 2016 and 2017, the $\mathrm{N}_{0}$ and $\mathrm{N}_{150}$ treatments resulted in lower values of Pn and Gs when compared with $\mathrm{N}_{225}$

Peer) reviewing PDF | (2020:06:50071:2:0:NEW 13 Sep 2020) 
250

251

252

253

254

255

256

257

258

259

260

261

262

263

264

265

266

267

268

269

270

271

272

273

274

275

276

277

278

279

280

281

282

283

284

285

286

287

288

289

and $\mathrm{N}_{300}$; however, the effect of $\mathrm{N}_{225}$ was relatively greater than that of the $\mathrm{N}_{300}$ treatment at R6. This finding indicates that $\mathrm{N}$ fertilizer inputs can increase Gs and improve the photosynthetic capacity of maize crops. Conversely, the Pn and Gs of the $\mathrm{N}_{300}$ treatment were reduced compared with $\mathrm{N}_{225}$. Pn of $\mathrm{N}_{150}, \mathrm{~N}_{225}$, and $\mathrm{N}_{300}$ increased ranging from $16 \%$ to $81 \%$ across growth stages compared with $\mathrm{N}_{0}$ averaged of two years. $\mathrm{N}$ application rates significantly affected 1-Ci/Ca $(P<$ 0.05 ). The 1-Ci/Ca of the $\mathrm{N}_{0}$ treatment was significantly lower than that of $\mathrm{N}_{300}$ in all measurements (Fig. 2).

Overall, the leaf area index (LAI) was unaffected $(P=0.55)$ by $\mathrm{N}$ application rates, with an average of 2.6 and 3.7 at the V8 and VT stages (Fig. 2). N application rates significantly affected LAI at the R3 and R6 stages. Compared with $\mathrm{N}_{300}$, the LAI of $\mathrm{N}_{225}, \mathrm{~N}_{150}$ and $\mathrm{N}_{0}$ decreased by $1 \%, 6 \%, 11 \%$, respectively, and $1 \%, 7 \%$, and $13 \%$, respectively, at the R3 and R6 stages.

\section{Root System}

The root dry weight reached a maximum value with the $\mathrm{N}_{225}$ treatment. Root dry weight of $\mathrm{N}_{225}$ increased ranging from $35 \%$ to $67 \%$ compared with $\mathrm{N}_{0}$, while $\mathrm{N}_{300}$ increased the root dry weight ranging from $29 \%$ to $53 \%$ compared with $\mathrm{N}_{0}$ average of two years (Table 4 ). We observed clear differences in the vertical distributions of roots as well as root morphology between $\mathrm{N}$ application rates, including root volume, root surface area, and root length density, which varied with $\mathrm{N}$ application rates and years (Table 5). After the VT stage, the root system distributed in the surface layer $(0-30 \mathrm{~cm})$ accounted for greater than $88 \%$ of the root weight for all treatments. At the V8 stage, the root ratio was proportional to the $\mathrm{N}$ application rate and increased significantly in the middle layer $(30-60 \mathrm{~cm})$. In the $\mathrm{N}_{0}$ treatment, almost all roots were concentrated in the surface soil layer. The $\mathrm{N}_{0}$ treatment exhibited significant increases in the deep-layer $(60-90 \mathrm{~cm})$ root ratio at the VT stage. The root ratio in the deep soil layer decreased with increasing $\mathrm{N}$ application after the VT stage. At the R3 and R6 stages, the surface root ratio increased with increasing $\mathrm{N}$ application rate. For the $\mathrm{N}_{0}$ treatment, the deep-layer root ratio decreased after the VT stage. Similar to the dry root weight, root morphology indexes (root volume, surface area, and length density) increased initially and then decreased with increasing $\mathrm{N}$ application rate. These indexes reached their maximum values under the $\mathrm{N}_{225}$ treatment. At the V8 stage, root morphology indexes were in the order of $\mathrm{N}_{225}>\mathrm{N}_{300}>\mathrm{N}_{150}>\mathrm{N}_{0}$ in the surface soil layer, which differed from the middle soil layer $\left(\mathrm{N}_{300}>\mathrm{N}_{225}>\mathrm{N}_{150}>\mathrm{N}_{0}\right)$. Larger roots appeared in deep soil layers at the VT stage when compared to the V8 stage, and the maximum value (root volume, surface area, and length density) for the $\mathrm{N}_{0}$ treatment was observed in the middle or deep soil layers. At the R3 and R6 stages, trends in root morphology indexes varied between soil layers; in the surface layer, the indexes followed the order $\mathrm{N}_{225}>\mathrm{N}_{300}>\mathrm{N}_{150}>\mathrm{N}_{0}$; in the middle layer, $\mathrm{N}_{225}>\mathrm{N}_{150}>\mathrm{N}_{300}>\mathrm{N}_{0}$; and in the deep layer, $\mathrm{N}_{225}>\mathrm{N}_{150}>\mathrm{N}_{0}>\mathrm{N}_{300}$.

\section{Discussion}

An optimal rate of $\mathrm{N}$ application is expected to produce a balance between crop demand and $\mathrm{N}$ supply and ensure maximum crop production while conserving resources and protecting against environmental damage (Ciampitti and Vyn, 2011; Peng, Li and Fritschi, 2014). Our results showed that during the 2017 growing season, even when photosynthesis was significantly 
290

291

292

293

294

295

296

297

298

299

300

301

302

303

304

305

306

307

308

309

310

311

312

313

314

315

316

317

318

319

320

321

322

323

324

325

326

327

328

affected by a $50 \%$ reduction in $\mathrm{N}$ application $\left(\mathrm{N}_{150}\right)$, grain yield was not significantly decreased. In 2016, photosynthetic parameters decreased further for the $\mathrm{N}_{150}$ and $\mathrm{N}_{0}$ treatments, and the grain yield also decreased significantly. Over 4 years, we observed no significant reduction in grain yield for the $\mathrm{N}_{225}$ treatment (Table 2), which even displayed a grain yield higher than that of the $\mathrm{N}_{300}$ treatment, although the difference was not significant. Our research indicated that the $\mathrm{N}$ dose could be reduced by at least $25 \%$ without compromising grain production. Our results are similar to those of Li et al. (2007) and Lamptey et al. (2017), who reported an optimal N fertilization range for summer maize of 200 to $300 \mathrm{~kg} \mathrm{~N} \mathrm{ha}^{-1}$. Under the $\mathrm{N}_{0}$ and $\mathrm{N}_{150}$ treatments, dry matter accumulation was limited, and the difference between $\mathrm{N}_{300}$ and $\mathrm{N}_{225}$ treatments was not significant. The reduction in crop yield induced by $\mathrm{N}$ reduction can be explained by various factors, as described below.

Our experiments also addressed the mechanism by which maize yield is affected by $\mathrm{N}$ application rates. We found that for most years, IPAR was not affected by $\mathrm{N}$ fertilizer application rates, a finding similar to that described in previous studies (Vos, Van Der Putten and Birch, 2005; Massignam et al., 2012). $\mathrm{N}$ application rate significantly affected RUE $(P<0.05)$. For $\mathrm{N}_{0}$ and $\mathrm{N}_{150}$, the RUE was significantly less than that of $\mathrm{N}_{300}$. However, the RUE of the $\mathrm{N}_{225}$-treated crop was greater than that of the $\mathrm{N}_{300}$-treated crop. In this case, lower grain yield driven by lower $\mathrm{N}$ treatment corresponded to lower RUE. These results indicate that under such production conditions, $\mathrm{N}$ application rate mainly affects grain yield by affecting RUE rather than IPAR. Vos, Van Der Putten, and Birch (2005) also found that maize tends to sacrifice specific leaf N and RUE while maintaining leaf area [small changes to leaf area index (LAI, Fig. 2) in comparison with the large decrease in Pn (Fig. 2) at low N application rates]. Therefore, in the condition of high IPAR, improving the RUE may represent a valid mechanism to achieve high maize grain yield.

The actual ET involves two components: crop transpiration and soil evaporation. $\mathrm{N}$ application can increase ET during the reproductive period due to high leaf transpiration under high N conditions (Lamptey et al., 2017; Rudnick et al., 2017). The relatively low sensitivity of IPAR to N supply in maize may also be consistent with the low sensitivity of soil evaporation to $\mathrm{N}$ supply. In this case, the lower grain yields associated with the $\mathrm{N}_{0}$ treatments corresponded to lower ET and WUE values. In addition, WUE of the $\mathrm{N}_{300}$-treated crop was lower than that of the $\mathrm{N}_{225}$-treated crop. This is due to a higher sensitivity to soil water by the plant at higher $\mathrm{N}$ application rates. An increase in $\mathrm{N}$ application rates is usually accompanied by a decrease in NUE (Ju et al., 2015). Significant effects of N were also observed on N use efficiency (NUE including AEN, REN, NHI, and INE) in our study. Conversely, reducing the N application rate can create a balance between crop demand and $\mathrm{N}$ supply (Lamptey et al., 2017). The desired $\mathrm{N}$ concentration of the plant, under the $\mathrm{N}_{0}$ treatment, has a high INE value, indicating that the plant $\mathrm{N}$ concentration or yield are low and that the amount of $\mathrm{N}$ in the plant absorbed from the soil is small. $\mathrm{N}$ accumulation increased with increasing $\mathrm{N}$ application, but $\mathrm{N}$ accumulation in the grain was not significantly different between $\mathrm{N}_{225}$ and $\mathrm{N}_{300}$ treatments, and the value of $\mathrm{NHI}$ at $\mathrm{N}_{225}$

Peer] reviewing PDF | (2020:06:50071:2:0:NEW 13 Sep 2020) 
329

330

331

332

333

334

335

336

337

338

339

340

341

342

343

344

345

346

347

348

349

350

351

352

353

354

355

356

357

358

359

360

361

362

363

364

365

366

367

368

was greater than that at $\mathrm{N}_{300}$, which indicated that increased $\mathrm{N}$ in the plant did not transfer to the grain, resulting in excessive $\mathrm{N}$ absorption and residual $\mathrm{N}$ in the vegetative organs.

The plasticity of root morphology allows it to respond to soil mineral nutrients (Peng, Li and $\mathrm{Li}, 2012$; Yu et al., 2014). We found that root dry weight reached a maximum with the $\mathrm{N}_{225}$ treatment, which suggested that the relationship between $\mathrm{N}$ input and the root system is not linear and positive; $\mathrm{N}$ input may even have a negative impact on root growth and development. In the present study, application of $\mathrm{N}$ fertilizer promoted growth of roots in the $0-60 \mathrm{~cm}$ soil layer and increased the proportion of roots in this layer, indicating that $\mathrm{N}$ application improved growth of the upper layer roots. In the late growth stage (after VT), the $\mathrm{N}_{0}$ treatment exhibited a negative effect on the root dry weight and proportion in the $30-60 \mathrm{~cm}$ and $60-90 \mathrm{~cm}$ soil layers, indicating that $\mathrm{N}$ deficiency would be detrimental during the accelerated aging of deep layer roots. Not only are root morphology and nutrient absorption closely related, but the spatial distribution of roots is also closely connected to crop growth and productivity (Mi et al., 2010; Lynch, 2013). In both years, the root system exhibited the optimal distribution under the $\mathrm{N}_{225}$ treatment, with a higher root length density in the observed soil layer, resulting in larger and deeper infiltration scales. Slower root senescence in the $\mathrm{N}_{225}$ treatment is also a major contributor to $\mathrm{N}$ rate-induced increases in grain yield. Studies have shown that the relative stability of the deep root environment is beneficial in promoting the buffer capacity of the root system in adverse soil environments and achieving high grain yield and resource use efficiency (Chen et al., 2010; Mi et al., 2010; Wasson et al., 2012; Saengwilai et al., 2014). The results of our study during the 2016 and 2017 growing seasons showed that excessive $\mathrm{N}\left(\mathrm{N}_{300}\right)$ application negatively affects early deep root growth compared with $\mathrm{N}_{225}$. High external $\mathrm{N}$ input also appeared to generate an overall inhibitory effect on later root growth. There are many reasons for the observed reduction in crop yield. Slight reductions in crop yield induced by excessive $\mathrm{N}$ application may be due to negative impacts on root growth during the early growth stage or may be caused by differing mechanisms of aging leading to $\mathrm{N}$ loss and relative $\mathrm{N}$ deficiency during the reproductive stage. $\mathrm{N}$ deficiency induces root thinning and increases longitudinal expansion by promoting root growth in the deep soil, while high $\mathrm{N}$ inhibits vertical expansion of roots (Trachsel et al., 2013; Mu et al., 2015). This study explained the effect of excessive $\mathrm{N}$ and $\mathrm{N}$ deficiency on yield from the perspective of root morphology and growth.

The role of $\mathrm{N}$ in grain formation is mainly explained by photosynthesis, and $\mathrm{N}$ reduction usually negatively impacts photosynthetic performance in maize (Massignam et al., 2012; Olszewski et al., 2014). Although the $\mathrm{N}_{150}$ treatment significantly reduced $\mathrm{Pn}$ in the 2017 growing season, the grain yield for the $\mathrm{N}_{150}$ treatment was not significantly reduced, indicating that the plant's transient photosynthetic parameters were more sensitive than the dry mass factors in responding to changes in $\mathrm{N}$ application rates. Our results illustrate the physiological basis for utilizing the $225 \mathrm{~kg} \mathrm{ha}^{-1} \mathrm{~N}$ rate to improve the stress resistance of summer maize plants in the Loess Plateau. For the $\mathrm{N}_{300}$ treatment, decreased Pn was due to lower Gs, which may be due to $\mathrm{N}$-associated increased sensitivity of plant to soil water and results in lower WUE than the $\mathrm{N}_{225}$ treatment at the R6 stages. In the low-N treatment, maize plants showed reduced leaf rolling 
369

370

371

372

373

374

375

376

377

378

379

380

381

382

383

384

385

386

387

388

389

390

391

392

393

394

395

396

397

398

399

400

401

402

403

404

405

406

407

408

under soil water stress compared with the high $\mathrm{N}$ treatment and thus obtained higher WUE (Wang et al., 2019).

At different measurement dates, the maximum value of Gs was not always associated with the $\mathrm{N}_{300}$ treatment (Fig. 2). In general, plants' water requirements are expected be greater under high $\mathrm{N}$ conditions. Thus, high- $\mathrm{N}$ fertilizer plots are more likely to be water-deficient if the soil moisture is inadequate, which aggravates the plant's stomatal limitations $(1-\mathrm{Ci} / \mathrm{Ca})$ and resulting in reduction of Gs and Pn. Similar findings have been described in wheat (Zhang et al., 2017). Previous studies also pointed out that under soil water-stress, ABA (as the signal carrier) transmitted to the shoot, reducing the Gs and increasing stomatal limitations in the initial drought (Larcher, 2003; $\mathrm{Li}$ and $\mathrm{Xu}, 2014$; Yan et al., 2017). The inadequate soil moisture of the $\mathrm{N}_{300}$ treatment is not serious enough to affect non-stomatal factors restricting photosynthetic carbon assimilation. The Pn of the $\mathrm{N}_{225}$ treatment was similar to that of the $\mathrm{N}_{300}$ treatment during the VT stage, but it was less than that of the $\mathrm{N}_{225}$ treatment in R6. Although the $\mathrm{N}_{225}$ treatment showed a higher photosynthetic rate in the $\mathrm{R} 6$ than the $\mathrm{N}_{300}$ treatment, the ratio did not result in a significantly higher yield, which may be caused by the small contribution of high photosynthetic capacity to a grain yield (Acciaresi et al., 2014). In addition, the photosynthetic capacity may also be related to the differences in $\mathrm{N}$ nutrition characteristics among different maize genotypes (Chen et al., 2014; Li et al., 2015). Thus, while the application rate of $225 \mathrm{~kg} \mathrm{~N} \mathrm{ha}^{-1}$ was may still be high, the current $\mathrm{N}$ rate was relatively effective in improving resource use efficiencies. Under production conditions, large amounts of $\mathrm{N}$ input are often used as an "insurance" against higher yields to ensure further increases in maize production (Huang et al., 2007; Chen et al., 2012). However, this behavior results in a significant reduction in NUE (Chen et al., 2010) and a slight reduction of RUE and WUE. Previously, Chen et al. (2016) and Mu et al. (2018) reported that $\mathrm{N}$ is used primarily for cell morphogenesis, that $\mathrm{N}$ in leaves is $\mathrm{N}$ redundant, and excess $\mathrm{N}$ is mainly stored in soluble protein and light-harvesting pigment-protein complexes. Therefore, in our study, the grain yield of $\mathrm{N}_{225}$ treatment did not display significantly different results compared to the $\mathrm{N}_{300}$ treatment, and the root system and photosynthetic capacity showed certain advantages of $\mathrm{N}_{225}$ treatment. From these findings, we can conclude that it is achievable to improve resource use efficiencies while ensuring grain yield. Actually, maize genotypes and soil moisture also affect GY and physiological characteristics (Ciampitti et al., 2013). In the current experiment, these factors are not taken into consideration. In future studies, we will focus on the effects of genotype with the aim of maximizing GY and resource use efficiency.

\section{Conclusions}

Decreased grain yield due to $\mathrm{N}$ reduction was driven by reduced radiation utilization efficiency and water use efficiency; the impact of radiation interception and total water evapotranspiration were relatively small. An application rate of $225 \mathrm{~kg} \mathrm{~N} \mathrm{ha}^{-1}$ could be used as a reference for optimal $\mathrm{N}$ application in the Loess Plateau of China. This $\mathrm{N}$ application rate optimized the ecophysiological responses of the plant, a finding which was confirmed by measuring photosynthetic activity and the root system. This response to optimizing $\mathrm{N}$ input resulted in higher grain yield, RUE, WUE, and NUE. Reducing $\mathrm{N}$ application rates has strong recoverability 
409 in maize production and can maximize the capture and utilization of resources, increasing the 410 maize grain yield.

411

\section{References}

413 Acciaresi HA, Tambussi EA, Antonietta M, Zuluaga MS, Andrade FH, Guiamét JJ. 2014.

414 Carbon assimilation, leaf area dynamics, and grain yield in contemporary earlier- and later-

415 senescing maize hybrids. European Journal of Agronomy |59:29-38 DOI

$416 \quad$ 10.1016/j.eja.2014.05007.

417

418

419

420

421

422

423

424

425

426

427

428

429

430

431

432

433

434

435

436

437

438

439

440

441

442

443

444

445

446

447

Ahmad I, Kamran M, Ali S, Bilegjargal B, Cai T, Ahmad S, Meng XP, Su WN, Liu TN, Han QF. 2018. Uniconazole application strategies to improve lignin biosynthesis, lodging resistance and production of maize in semiarid regions. Field Crops Research 222:66-77 DOI 10.1016/j.fcr.2018.03.015.

Brown HE, Jamieson PD, Moot DJ. 2012. Predicting the transpiration of Lucerne. European Journal of Agronomy 43:9-17 DOI 10.1016/j.eja.2012.03.012.

Birch CJ, Vos J, Van Der Putten PEL. 2003. Plant development and leaf area production in contrasting cultivars of maize grown in a cool temperate environment in the field. European Journal Agronomy 19:173-188 DOI 10.1016/S1161-0301(02)00034-5.

Chen YL, Wu DL, Mu XH, Xiao CX, Chen FJ, Yuan LX, Mi GH. 2016. Vertical distribution of photosynthetic nitrogen use efficiency and its response to nitrogen in field-grown maize. Crop Science 56(1):397-407 DOI 10.2135/cropsci2015.03.0170.

Chang YL, Liu JM, Li YH, Sun BH, Zhang SL, Yang XY. 2014. Investigation and evaluation of nutrient input under winter wheat and summer maize rotation system in Guanzhong Plain of Shaanxi Province. Journal Northwest A \&F University 42:51-61 (in Chinese).

Chen GP, Gao JL, Zhao M, Dong ST, Li SK, Yang QF, Liu YH, Wang LC, Xue JQ, Liu JG, Li CH, Wang YH, Wang YD, Song HX, Zhao JR. 2012. Distribution, yield structure, and key cultural techniques of maize super-high yield plots in recent years. Acta Agronomica Sinica 38(1):80-85 DOI 10.3724/SP.J.1006.2012.00080.

Chen XP, Zhang FS, Cui ZL, Li F, Li JL. 2010. Optimizing soil nitrogen supply in the root zone to improve maize management. Soil Science Society of America Journal 74:1367-1373 DOI 10.2136/sssaj2009.0227.

Chen QW, Mu XH, Chen FJ, Yuan LX, Mi GH. 2016. Dynamic change of mineral nutrient content in different plant organs during the grain filling stage in maize grown under contrasting nitrogen supply. European Journal of Agronomy 80:137-153 DOI 10.1016/j.eja.2016.08.002.

Ciampitti IA, Vyn TJ. 2011. A comprehensive study of plant density consequences on nitrogen uptake dynamics of maize plants from vegetative to reproductive stages. Field Crops Research 121(1):2-18 DOI 10.1016/j.fcr.2010.10.009.

Ciampitti IA, Murrell ST, Camberato JJ, Tuinstra M, Xia Y, Friedemann P, Vyn TJ. 2013. Physiological dynamics ofmaize nitrogen uptake and partitioning in response to plant 
448

449

450

451

452

453

454

455

456

457

458

459

460

461

462

463

464

465

466

467

468

469

470

471

472

473

474

475

476

477

478

479

480

481

482

483

484

485

density and nitrogen stress factors: II. Reproductive phase. Crop Science 53:2588-2602 DOI 10.2135/cropsci2013.01.0041.

Cui ZL, Zhang FS, Mi GH, Chen FJ, Li F, Chen XP, Li JL, Shi LF. 2009. Interaction between genotypic difference and nitrogen management strategy in determining nitrogen use efficiency of summer maize. Plant Soil 317(1-2):267-276 DOI 10.1007/s11104-008-9807$\mathrm{x}$.

Dai J, Wang ZH, Li FC, He G, Wang S, Li Q, Cao HB, Luo LC, Zan YL, Meng XY, Zhang WW, Wang RH, Malhi SS. 2015. Optimizing nitrogen input by balancing winter wheat yield and residual nitrate- $\mathrm{N}$ in soil in a long-term dryland field experiment in the Loess Plateau of China. Field Crops Research 181:32-41 DOI 10.1016/j.fcr.2015.06.014.

Erisman JW, Galloway JN, Seitzinger S, Bleeker A, Dise NB, Petrescu AMR, Leach AM, de Vries W. 2013. Consequences of human modification of the global nitrogen cycle. Philosophical transactions of the Royal Society of London. Series B, Biological sciences 368(1621): 20130116 DOI 10.1098/rstb.2013.0116.

FAO. FAOSTAT-Agriculture Database. 2018. Available online: http://faostat.fao.org/site/

Fletcher AL, Johnstone PR, Chakwizira E, Brown HE. 2013. Radiation capture and radiation use efficiency in response to $\mathrm{N}$ supply for crop species with contrasting canopies. Field Crops Research 150(20):126-134. DOI 10.1016/j.fcr.2013.06.014.

Herrera JM, Rubio G, Häner LL, Delgado JA, Lucho-Constantino CA, Islas-Valdez S, Pellet D. 2016. Emerging and established technologies to increase nitrogen use efficiency of cereals. Agronomy 6(2):25 DOI 10.3390/agronomy6020025.

Holanda FSR, Mengel DB, Paula MB, Carvaho JG, Bertoni JC. 1998. Influence of crop rotations and tillage systems on phosphorus and potassium stratification and root distribution in the soil profile. Communications in Soil Science and Plant Analysis 29(15-16): 2383-2394 DOI $10.1080 / 00103629809370118$.

Huang YL, Chen LD, Fu BJ, Huang ZL, Gong J. 2005. The wheat yields and water-use efficiency in the loess plateau: straw mulch and irrigation effects. Agricultural Water Management 72(3):209-222 DOI 10.1016/j.agwat.2004.09.012.

Huang ZX, Wang YJ, Wang KJ, Li DH, Zhao M, Liu JG, Dong ST, Wang HJ, Wang JH, Yang JS. 2007. Photosynthetic characteristics during grain filling stage of summer maize hybrids with high yield potential of 15,000 kg ha-1. Scientia Agricultura Sinica 40(9):1898-1906 (in Chinese).

Ju CX, Buresh RJ, Wang ZQ, Zhang H, Liu LJ, Yang JC, Zhang JH. 2015. Root and shoot traits for rice varieties with higher grain yield and higher nitrogen use efficiency at lower nitrogen rates application. Field Crops Research 175:47-55 DOI 10.1016/j.fcr.2015.02.007.

Lamptey S, Li LL, Xie JH, Zhang RZ, Yeboah S, Antille DL. 2017. Photosynthetic response of maize to nitrogen fertilization in the semiarid western loess plateau of China. Crop Science 57(5):2739-2752 DOI 10.2135/cropsci2016.12.1021. 
486

487

488

489

490

491

492

493

494

495

496

497

498

499

500

501

502

503

504

505

506

507

508

509

510

511

512

513

514

515

516

517

518

519

520

521

522

523

Larcher W. 2003. Physiological plant ecology ecophysiology and stress: Physiology of functional groups. 4th ed. Springer Verlag, Berlin, Heidelberg pp513 DOI 10.1007/978-3662-05214-3.

Li DD, Tian MY, Cai J, Jiang D, Cao WX, Dai TB. 2013. Effects of low nitrogen supply on relationships between photosynthesis and nitrogen status at different leaf position in wheat seedlings. Plant Growth Regulation 70:257-263 DOI 10.1007/s10725-013-9797-4.

Li Q, Luo YH, Yu DH, Kong FL, Yang SM, Yuan JC. 2015. Effects of low nitrogen stress on photosynthetic characteristics and chlorophyll fluorescence parameters of maize cultivars tolerant to low nitrogen stress at the seedling stage. Journal of Plant Nutrition and Fertilizer 21(5):1132-1141 DOI 10.11674/zwyf.2015.0505.

Li QQ, Dong BD, Qiao YZ, Liu MY, Zhang JW. 2010. Root growth, available soil water, and water-use efficiency of winter wheat under different irrigation regimes applied at different growth stages in North China. Agricultural Water Management 97(10):1676-1682 DOI 10.1016/j.agwat.2010.05.025.

Li X, Xu K. 2014. Effects of exogenous hormones on leaf photosynthesis of Panax ginseng. Photosynthetica 52:152-156 DOI 10.1007/s11099-014-0005-1.

Li XX, Hu CS, Delgado JA, Zhang YM, Ouyang ZY. 2007. Increased nitrogen use efficiencies as a key mitigation alternative to reduce nitrate leaching in north China plain. Agricultural Water Management 89(12):137-147 DOI 10.1016/j.agwat.2006.12.012.

Liang HY, Shen PF, Kong XZ, Liao YC, Liu Y, Wen XX. 2020. Optimal nitrogen practice in winter wheat-summer maize rotation affecting the fates of $15 \mathrm{~N}$-labeled fertilizer. Agronomy 10:521 DOI 10.3390/agronomy 10040521.

Liu CA, Zhou LM, Jia JJ, Wang LJ, Si JT, Li X, Pan CC, Siddique KHM, Li FM. 2014. Maize yield and water balance is affected by nitrogen application in a film-mulching ridge-furrow system in a semiarid region of China. European Journal Agronomy 52:103-111 DOI 10.1016/j.eja.2013.10.001.

Lynch JP. 2013. Steep, cheap and deep: an ideotype to optimize water and $\mathrm{N}$ acquisition by maize root systems. Annal of Botany 112:347-357 DOI 10.1093/aob/mcs293.

Massignam AM, Chapman SC, Hammer GL, Fukai S. 2012. Effects of nitrogen supply on canopy development of maize and sunflower. Crop Pasture Science 62:1045-1055.

McBratney A, Field D. 2015. Securing our soil. Soil Science and Plant Nutrition 61:587-591 DOI 10.1080/00380768.2015.1071060.

Meng QF, Yue SC, Hou P, Cui ZL, Chen XP. 2016. Improving yield and nitrogen use efficiency simultaneously for maize and wheat in China: a review. Pedosphere 26(2):137-147 DOI 10.1016/S1002-0160(15)60030-3.

Mi GH, Chen FJ, Wu QP, Lai NW, Yuan LX, Zhang FS. 2010. Ideotype root architecture for efficient nitrogen acquisition by maize in intensive cropping systems. Science China-Life Sciences 53(12):1369-1373 DOI 10.1007/s11427-010-4097-y. 
524

525

526

527

528

529

530

531

532

533

534

535

536

537

538

539

540

541

542

543

544

545

546

547

548

549

550

551

552

553

554

555

556

557

558

559

560

561

562

563

Mu XH, Chen QW, Chen FJ, Yuan LX, Mi GH. 2017. A RNA-Seq analysis of the response of photosynthetic system to low nitrogen supply in maize leaf. International Journal of Molecular Sciences 18(12):2624 DOI 10.3390/ijms18122624.

Mu XH, Chen FJ, Wu QP, Chen QW, Wang JF, Yuan LX, Mi GH. 2015. Genetic improvement of root growth increases maize yield via enhanced post-silking nitrogen uptake. European Journal Agronomy 63:55-61 DOI 10.1016/j.eja.2014.11.009.

Mu XH, Chen QW, Chen FJ, Yuan LX, Mi GH. 2018. Dynamic remobilization of leaf nitrogen components in relation to photosynthetic rate during grain filling in maize. Plant Physiology and Biochemistry 129:27-34 DOI 10.1016/j.plaphy.2018.05.020.

Nelson DW, Sommers LE. 1973. Determination of total nitrogen in plant material. Agronomy Journal 65(1):109 DOI 10.2134/jeq1972.00472425000100040020x.

Olszewski J, Makowska M, Pszczółkowska A, Okorski A, Bieniaszewski T. 2014. The effect of nitrogen fertilization on flag leaf and ear photosynthesis and grain yield of spring wheat. Plant Soil and Environment 60(12):531-536 DOI 10.17221/880/2013-PSE.

Peng YF, Li C, Fritschi FB. 2014. Diurnal dynamics of maize leaf photosynthesis and carbohydrate concentrations in response to differential $\mathrm{N}$ availability. Environmental and Experimental Botany 99:18-27 DOI 10.1016/j.envexpbot.2013.10.013.

Peng YF, Li XX, Li CJ. 2012. Temporal and spatial profiling of root growth revealed novel response of maize roots under various nitrogen supplies in the field. PLoS ONE 7(5):e37726 DOI 10.1371/journal.pone.0037726.

Qiang SC, Zhang Y, Fan JL, Zhang FC, Xiang YZ, Yan SC, Wu Y. 2019. Maize yield, rainwater and nitrogen use efficiency as affected by maize genotypes and nitrogen rates on the Loess Plateau of China. Agricultural Water Management 213:996-1003 DOI 10.1016/j.agwat.2018.12.021.

Ristova D, Busch W. 2014. Natural variation of root traits: from development to nutrient uptake. Plant Physiology 166(2):518-527 DOI 10.1104/pp.114.244749.

Ritchie SW, Hanway JJ. 1982. How a corn plant develops. Spec. Rep. 48. Rev. Iowa State University, Coop. Ext. Serv., Ames IA.

Robertson GP, Vitousek PM. 2009. Nitrogen in agriculture: balancing the cost of an essential resource. Annual Review of Environment and Resources 34(1):97-125 DOI 10.1146/annurev.environ.032108.105046.

Rudnick DR, Irmak S, Djaman K, Sharma V. 2017. Impact of irrigation and nitrogen fertilizer rate on soil water trends and maize evapotranspiration during the vegetative and reproductive periods. Agriculture Water Management 191:77-84 DOI 10.1016/j.agwat.2017.06.007.

Saengwilai P, Nord EA, Chimungu JG, Brown KM, Lynch JP. 2014. Root cortical aerenchyma enhances nitrogen acquisition from low-nitrogen soils in maize. Plant Physiology 166(2):726-735 DOI 10.1104/pp.114.241711.

Suchy M, Wassenaar LI, Graham G, Zebarth B. 2018. High-frequency NO3- isotope (delta N-15, delta O-18) patterns in groundwater recharge reveal that short-term changes in land use and 
564

565

566

567

568

569

570

571

572

573

574

575

576

577

578

579

580

581

582

583

584

585

586

587

588

589

590

591

592

593

594

595

596

597

598

599

600

601

602

precipitation influence nitrate contamination trends. Hydrology and Earth System Science 22:4267-4279 DOI 10.5194/hess-22-4267-2018.

Trachsel S, Kaeppler SM, Browm KM, Lynch JP. 2013. Maize root growth angles become steeper under low N conditions. Field Crops Research 140:18-31 DOI 10.1016/j.fcr.2012.09.010.

Vos J, Van Der Putten PEL, Birch CJ. 2005. Effect of nitrogen supply on leaf appearance leaf growth leaf nitrogen economy and photosynthetic capacity in maize (Zea mays L). Field Crops Research 93(1):64-73 DOI 10.1016/j.fcr.2004.09.013.

Wang GL, Ye YL, Chen XP, Cui ZL. 2014. Determining the optimal nitrogen rate for summer maize in China by integrating agronomic, economic, and environmental aspects. Biogeosciences 11:3031-3041 DOI 10.5194/bg-11-3031-2014.

Wang SQ, Wei SC, Liang HY, Zheng WB, Li XX, Hu CS, Currell MJ, Zhou F, Min LL. 2019. Nitrogen stock and leaching rates in a thick vadose zone below areas of long- term nitrogen fertilizer application in the North China Plain: A future groundwater quality threat. Journal of Hydrology 576:28-40 DOI 10.1016/j.jhydrol.2019.06.012.

Wang Y, Zhang XY, Chen J, Chen AJ, Wang LY, Guo XY, Niu YL, Liu SR, Mi GH, Gao Q. 2019. Reducing basal nitrogen rate to improve maize seedling growth, water and nitrogen use efficiencies under drought stress by optimizing root morphology and distribution. Agriculture Water Management 212:328-337 DOI 10.1016/j.agwat.2018.09.010.

Wasson AP, Richards RA, Chatrath R, Misra SC, Prasad SVV, Rebetzke GJ, Kirkegaard JA. 2012. Traits and selection strategies to improve root systems and water uptake in waterlimited wheat crops. Journal of Experimental Botany 63(9):3485-3498 DOI 10.1093/jxb/ers111.

Yan H, Wu LF, Filardo F, Yang XX, Zhao XM, Fu DH. 2017. Chemical and hydraulic signals regulate stomatal behavior and photosynthetic activity in maize during progressive drought. Acta Physiologiae Plantarum 39:125 DOI 10.1007/s11738-017-2418-5.

Yang XL, Lu YL, Ding Y, Yin XF, Raza S, Tong YA. 2017. Optimising nitrogen fertilisation: A key to improving nitrogen-use efficiency and minimising nitrate leaching losses in an intensive wheat/maize rotation (2008-2014). Field Crops Research 206:1-10 DOI 10.1016/j.fcr.2017.02.016.

Yu P, White PJ, Hochholdinger, F, Li C. 2014. Phenotypic plasticity of the maize root system in response to heterogeneous nitrogen availability. Planta 240:667-678 DOI 10.1007/s00425014-2150-y.

Zhang SL, Gao PC, Tong YA, Norse D, Lu YL, Powlson D. 2015a. Overcoming nitrogen fertilizer over-use through technical and advisory approaches: a case study from Shaanxi province, northwest China. Agriculture Ecosystems \&Environment 209:89-99 DOI 10.1016/j.agee.2015.03.002.

Zhang X, Davidson EA, Mauzerall DL, Searchinger TD, Dumas P, Shen Y. 2015b. Managing nitrogen for sustainable development. Nature 528(7580):51-59 DOI 10.1038/nature15743. 
603 Zhang XD, Yang LC, Xue XK, Kamran M, Ahmad I, Dong ZY, Liu TN, Jia ZK, Zhang P, Han 604 QF. 2019. Plastic film mulching stimulates soil wet-dry alternation and stomatal behavior to 605 improve maize yield and resource use efficiency in a semi-arid region. Field Crops

606 Research 233:101-113 DOI 10.1016/j.fcr.2019.01.002.

607 Zhang YQ, Wang JD, Gong SH, Xu D, Sui J. 2017. Nitrogen fertigation effect on

608 photosynthesis, grain yield and water use efficiency of winter wheat. Agriculture Water 609 Management 179:277-287 DOI 10.1016/j.agwat.2016.08.007.

610 Zhao BQ, Li XY, Li XP, Shi XJ, Huang SM, Wang BR, Zhu P, Yang XY, Liu H, Chen Y, 611 Poulton PR, Powlson DS, Todd AD, Payne RW. 2010. Long-term fertilizer experiment

612 network in China: crop yields and soil nutrient trends. Agronomy Journal 102(1):216-230

613 DOI 10.2134/agronj2009.0182. 
Figure 1

Daily mean temperature and precipitation during the maize growing seasons in 2014 (a), 2015(b), 2016(c) and 2017 (d) at the experimental site.
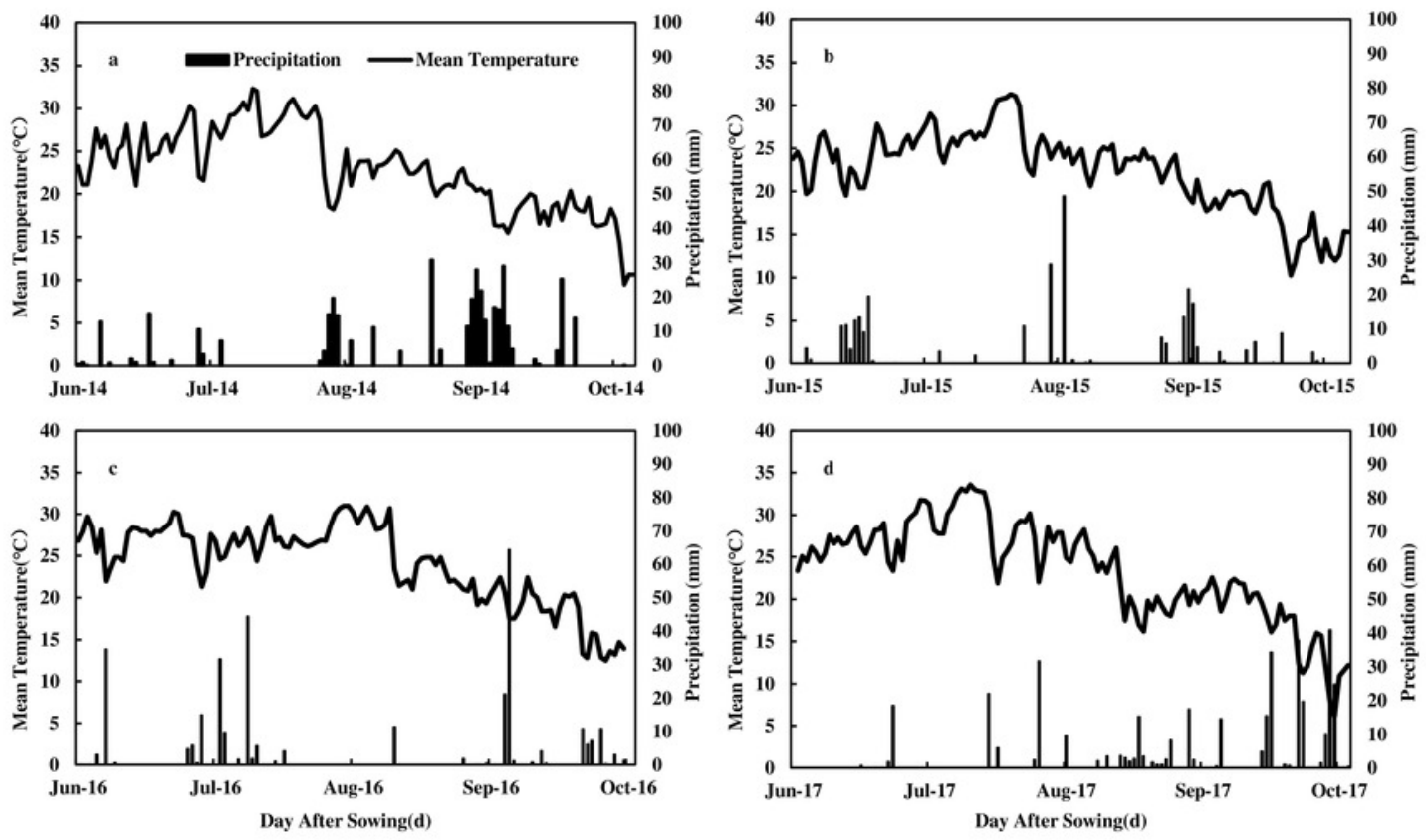
Figure 2

Effects of nitrogen application rates on Pn, Gs, 1-Ci/Ca and leaf area index (LAI) in 2016 (a-c) and 2017 (d-f) growing seasons

$\mathrm{N}_{300}, \mathrm{~N}_{225}, \mathrm{~N}_{150}$ and $\mathrm{N}_{0}$ represent application of nitrogen at a rate of $300,225,150$ and $0 \mathrm{~kg}$

ha $a^{-1}$. Vertical bars represent the (means \pm SD) $(n=3)$. 

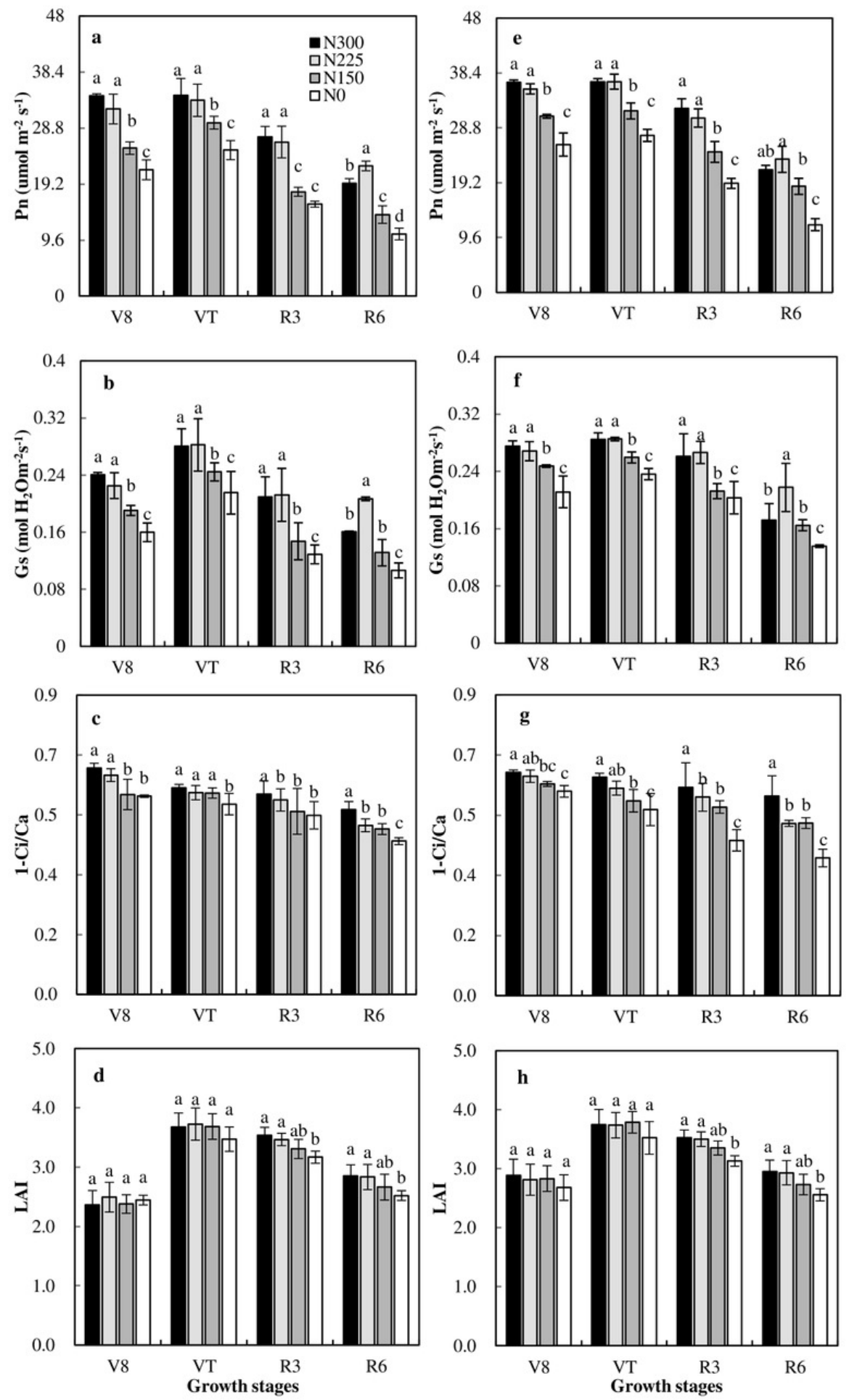


\section{Table 1 (on next page)}

Soil chemical properties of the top 0-60 cm layers in the experimental fields 


\begin{tabular}{lccccc}
\hline Layer $(\mathrm{cm})$ & $\begin{array}{c}\text { Organic matter } \\
\left(\mathrm{g} \mathrm{kg}^{-1}\right)\end{array}$ & $\begin{array}{c}\text { Total nitrogen } \\
\left(\mathrm{g} \mathrm{kg}^{-1}\right)\end{array}$ & $\begin{array}{c}\text { Alkaline nitrogen } \\
\left(\mathrm{mg} \mathrm{kg}^{-1}\right)\end{array}$ & $\begin{array}{c}\text { Available phosphorus } \\
\left(\mathrm{mg} \mathrm{kg}^{-1}\right)\end{array}$ & $\begin{array}{c}\text { Available potassium } \\
\left(\mathrm{mg} \mathrm{kg}^{-1}\right)\end{array}$ \\
\hline $0-20$ & 15.43 & 1.203 & 67.38 & 12.19 & 161.17 \\
$20-40$ & 14.02 & 0.987 & 44.89 & 9.03 & 117.21 \\
$40-60$ & 13.46 & 1.069 & 45.98 & 6.96 & 102.67 \\
\hline
\end{tabular}




\section{Table 2 (on next page)}

Effects of nitrogen application rates on grain yield (GY), biomass yield (BY), grain nitrogen content (GNC), $\mathrm{N}$ harvest index (NHI) and agronomic $\mathrm{N}$ use efficiency (AEN), apparent $\mathrm{N}$ recovery efficiency (RNE)

Means followed by different lowercase letters indicate significantly different $(p<0.05)$ within the same column and the same year. $\mathrm{N}_{300}, \mathrm{~N}_{225}, \mathrm{~N}_{150}$ and $\mathrm{N}_{0}$ represent application of nitrogen at a rate of $300,225,150$ and $0 \mathrm{~kg} \mathrm{ha}^{-1} . *$ Significant at the 0.05 probability level. ** Significant at the 0.01 probability level. ns, non-significant 


\begin{tabular}{|c|c|c|c|c|c|c|c|}
\hline Year & Nitrogen rates & $\begin{array}{c}\mathrm{GY} \\
\left(\mathrm{t} \mathrm{ha}^{-1}\right)\end{array}$ & $\begin{array}{c}\text { BY } \\
\left(\mathrm{kg} \mathrm{ha}^{-1}\right)\end{array}$ & $\begin{array}{c}\text { GNC } \\
\left(\mathrm{kg} \mathrm{ha}^{-1}\right)\end{array}$ & NHI & $\begin{array}{c}\mathrm{AEN} \\
\left(\mathrm{kg} \mathrm{kg}^{-1}\right)\end{array}$ & $\begin{array}{c}\text { REN } \\
\left(\mathrm{kg} \mathrm{kg}^{-1}\right)\end{array}$ \\
\hline \multirow[t]{4}{*}{2014} & $\mathrm{~N}_{300}$ & $10.2 \mathrm{a}$ & $18.1 \mathrm{a}$ & $127 \mathrm{a}$ & $59.4 \mathrm{~b}$ & $7.6 \mathrm{~b}$ & $38.4 \mathrm{~b}$ \\
\hline & $\mathrm{N}_{225}$ & $10.5 \mathrm{a}$ & $17.9 \mathrm{a}$ & $128 \mathrm{a}$ & $64.5 \mathrm{a}$ & $11.5 \mathrm{a}$ & $44.5 \mathrm{a}$ \\
\hline & $\mathrm{N}_{150}$ & $9.4 \mathrm{a}$ & $16.4 \mathrm{~b}$ & $105 b$ & $64.3 \mathrm{a}$ & $9.9 \mathrm{ab}$ & $43.1 \mathrm{ab}$ \\
\hline & $\mathrm{N}_{0}$ & $7.9 \mathrm{~b}$ & $13.6 \mathrm{c}$ & $61 \mathrm{c}$ & $62.0 \mathrm{ab}$ & - & - \\
\hline \multirow[t]{4}{*}{2015} & $\mathrm{~N}_{300}$ & $10.7 \mathrm{a}$ & $18.6 \mathrm{a}$ & $134 \mathrm{a}$ & $63.1 \mathrm{~b}$ & $8.1 b$ & $35.3 b$ \\
\hline & $\mathrm{N}_{225}$ & $11.1 \mathrm{a}$ & $18.6 \mathrm{a}$ & $133 a$ & $67.3 \mathrm{a}$ & $12.5 \mathrm{a}$ & $41.0 \mathrm{a}$ \\
\hline & $\mathrm{N}_{150}$ & $10.2 \mathrm{a}$ & $17.3 b$ & $111 \mathrm{~b}$ & $66.1 \mathrm{a}$ & $12.8 \mathrm{a}$ & $41.3 \mathrm{a}$ \\
\hline & $\mathrm{N}_{0}$ & $8.3 b$ & $14.4 \mathrm{c}$ & $68 \mathrm{c}$ & $64.7 b$ & - & - \\
\hline \multirow[t]{4}{*}{2016} & $\mathrm{~N}_{300}$ & $11.3 \mathrm{a}$ & $20.0 \mathrm{a}$ & $142 \mathrm{a}$ & $60.5 \mathrm{~b}$ & $8.5 b$ & $38.7 b$ \\
\hline & $\mathrm{N}_{225}$ & $11.4 \mathrm{a}$ & $19.8 \mathrm{a}$ & $134 \mathrm{a}$ & $63.6 \mathrm{a}$ & $12.1 \mathrm{a}$ & $41.6 \mathrm{ab}$ \\
\hline & $\mathrm{N}_{150}$ & $9.7 \mathrm{~b}$ & $18.4 \mathrm{~b}$ & $113 b$ & $59.0 \mathrm{~b}$ & $6.9 b$ & $48.6 \mathrm{a}$ \\
\hline & $\mathrm{N}_{0}$ & $8.7 \mathrm{c}$ & $15.6 \mathrm{c}$ & $70 \mathrm{c}$ & $59.1 \mathrm{~b}$ & - & - \\
\hline \multirow[t]{4}{*}{2017} & $\mathrm{~N}_{300}$ & $11.0 \mathrm{a}$ & $20.0 \mathrm{a}$ & $137 \mathrm{a}$ & $61.4 \mathrm{~b}$ & $7.2 \mathrm{~b}$ & $37.2 b$ \\
\hline & $\mathrm{N}_{225}$ & $11.4 \mathrm{a}$ & $20.0 \mathrm{a}$ & $138 \mathrm{a}$ & $65.1 \mathrm{a}$ & $11.5 \mathrm{a}$ & $45.0 \mathrm{a}$ \\
\hline & $\mathrm{N}_{150}$ & $10.5 \mathrm{a}$ & $18.5 \mathrm{~b}$ & $116 b$ & $63.2 \mathrm{ab}$ & $11.1 \mathrm{a}$ & $47.7 \mathrm{a}$ \\
\hline & $\mathrm{N}_{0}$ & $8.8 \mathrm{~b}$ & $15.6 \mathrm{c}$ & $70 \mathrm{c}$ & $62.7 \mathrm{~b}$ & - & - \\
\hline \multicolumn{8}{|c|}{ Source of variation } \\
\hline & Nitrogen rates $(\mathrm{N})$ & $* *$ & $* *$ & $* *$ & $* *$ & $* *$ & $* *$ \\
\hline & Year(Y) & $* *$ & $* *$ & $* *$ & $* *$ & $* *$ & $* *$ \\
\hline & $\mathrm{Nx} \mathrm{Y}$ & $\mathrm{ns}$ & $\mathrm{ns}$ & ns & ns & ns & $\mathrm{ns}$ \\
\hline
\end{tabular}

1 


\section{Table 3 (on next page)}

Effect of nitrogen application rates on evapotranspiration (ET), the accumulated intercepted solar radiation (IPAR), shoot nitrogen content (SNC), internal $\mathrm{N}$ use efficiency (INE), radiation use efficiencies (RUE), and water use efficiency (WUE)

Means followed by different lowercase letters within each column indicate significantly different $(p<0.05) . N_{300}, N_{225}, N_{150}$ and $N_{0}$ represent application of nitrogen at a rate of 300 , 225, 150 and $0 \mathrm{~kg} \mathrm{ha}^{-1}$. ET, total evapotranspiration (mm); IPAR, the accumulated intercepted solar radiation $\left(\mathrm{MJ} \mathrm{m} \mathrm{m}^{-2}\right), \mathrm{SNC}$, shoot nitrogen content $\left(\mathrm{kg} \mathrm{ha}^{-1}\right)$, IEN, internal $\mathrm{N}$ use efficiency $\left(\mathrm{kg} \mathrm{kg}^{-1}\right)$; RUE, radiation use efficiency; WUE, water use efficiency. * Significant at the 0.05 probability level. $* *$ Significant at the 0.01 probability level. ns, non-significant. 


\begin{tabular}{|c|c|c|c|c|c|c|c|}
\hline Year & Nitrogen rate & $\begin{array}{c}\text { ET } \\
(\mathrm{mm})\end{array}$ & $\begin{array}{c}\text { IPAR } \\
\left(\mathrm{MJ} \mathrm{m}^{-2}\right)\end{array}$ & $\begin{array}{c}\text { SNC } \\
\left(\mathrm{kg} \mathrm{ha}^{-1}\right)\end{array}$ & $\begin{array}{c}\text { IEN } \\
\left(\mathrm{kg} \mathrm{kg}^{-1}\right)\end{array}$ & RUE & WUE \\
\hline \multirow[t]{4}{*}{2014} & $\mathrm{~N}_{300}$ & $350 \mathrm{a}$ & $974 a$ & $214 \mathrm{a}$ & $47.8 \mathrm{c}$ & $1.96 \mathrm{a}$ & $29.1 \mathrm{a}$ \\
\hline & $\mathrm{N}_{225}$ & $346 a$ & $960 a$ & $198 \mathrm{a}$ & $53.1 b$ & $2.05 \mathrm{a}$ & $30.4 a$ \\
\hline & $\mathrm{N}_{150}$ & $343 a$ & $989 a$ & $163 b$ & $57.6 \mathrm{~b}$ & $1.77 \mathrm{~b}$ & $27.4 b$ \\
\hline & $\mathrm{N}_{0}$ & $333 b$ & $906 b$ & $98 \mathrm{c}$ & $81.6 \mathrm{a}$ & $1.63 \mathrm{c}$ & $23.8 \mathrm{c}$ \\
\hline \multirow[t]{4}{*}{2015} & $\mathrm{~N}_{300}$ & $336 a$ & $1181 \mathrm{a}$ & $212 \mathrm{a}$ & $50.5 d$ & $1.69 \mathrm{a}$ & $31.8 \mathrm{a}$ \\
\hline & $\mathrm{N}_{225}$ & $337 \mathrm{a}$ & $1179 a$ & $198 \mathrm{a}$ & $55.9 \mathrm{c}$ & $1.75 \mathrm{a}$ & $32.9 \mathrm{a}$ \\
\hline & $\mathrm{N}_{150}$ & $317 \mathrm{ab}$ & $1131 \mathrm{a}$ & $168 b$ & $60.8 b$ & $1.68 \mathrm{a}$ & $32.1 \mathrm{a}$ \\
\hline & $\mathrm{N}_{0}$ & $303 b$ & $1138 \mathrm{a}$ & $106 \mathrm{c}$ & $78.1 \mathrm{a}$ & $1.35 \mathrm{~b}$ & $27.2 \mathrm{~b}$ \\
\hline \multirow[t]{4}{*}{2016} & $\mathrm{~N}_{300}$ & $414 \mathrm{a}$ & $1141 \mathrm{a}$ & $234 a$ & $48.1 \mathrm{c}$ & $1.84 \mathrm{a}$ & $27.2 \mathrm{a}$ \\
\hline & $\mathrm{N}_{225}$ & $416 a$ & $1124 \mathrm{a}$ & $212 \mathrm{a}$ & $54.0 \mathrm{~b}$ & $1.89 \mathrm{a}$ & $27.5 \mathrm{a}$ \\
\hline & $\mathrm{N}_{150}$ & $399 a b$ & $1120 \mathrm{a}$ & $191 b$ & $51.0 \mathrm{~b}$ & $1.62 \mathrm{~b}$ & $24.4 b$ \\
\hline & $\mathrm{N}_{0}$ & $396 b$ & $1102 \mathrm{a}$ & $118 \mathrm{c}$ & $74.2 \mathrm{a}$ & $1.47 \mathrm{c}$ & $22.0 \mathrm{c}$ \\
\hline \multirow[t]{4}{*}{2017} & $\mathrm{~N}_{300}$ & $420 \mathrm{a}$ & $1134 a$ & $223 a$ & $49.5 d$ & $1.82 \mathrm{a}$ & $26.3 \mathrm{ab}$ \\
\hline & $\mathrm{N}_{225}$ & $417 \mathrm{a}$ & $1121 \mathrm{a}$ & $213 a$ & $53.7 \mathrm{c}$ & $1.91 \mathrm{a}$ & $27.5 a$ \\
\hline & $\mathrm{N}_{150}$ & 409ab & $1122 \mathrm{a}$ & $183 b$ & $57.5 b$ & $1.75 b$ & $25.8 b$ \\
\hline & $\mathrm{N}_{0}$ & $392 b$ & $1100 \mathrm{a}$ & $112 \mathrm{c}$ & $79.4 a$ & $1.50 \mathrm{c}$ & $22.6 \mathrm{c}$ \\
\hline \multicolumn{8}{|c|}{$\begin{array}{l}\text { Source of } \\
\text { variation }\end{array}$} \\
\hline & Nitrogen $(\mathrm{N})$ & $*$ & $*$ & $* *$ & $* *$ & $* *$ & $* *$ \\
\hline & Year(Y) & $* *$ & $* *$ & $* *$ & $*$ & $*$ & $* *$ \\
\hline & Nx Y & ns & ns & ns & ns & ns & ns \\
\hline
\end{tabular}

1 


\section{Table 4 (on next page)}

Effect of nitrogen application rates on root dry matter and root ratio

Means followed by different lowercase letters within each column indicate significantly

different $(p<0.05) . N_{300}, N_{225}, N_{150}$ and $N_{0}$ represent application of nitrogen at a rate of 300 , 225, 150 and $0 \mathrm{~kg} \mathrm{ha}^{-1}$. 


\begin{tabular}{|c|c|c|c|c|c|c|c|c|c|c|}
\hline \multirow{2}{*}{ Year } & \multirow{2}{*}{$\begin{array}{c}\text { Soil } \\
\text { layer }\end{array}$} & \multirow{2}{*}{$\begin{array}{c}\text { Nitrogen } \\
\text { rate }\end{array}$} & \multicolumn{4}{|c|}{ Root dry matter (g plant ${ }^{-1}$ ) } & \multicolumn{4}{|c|}{ Root ratio \% } \\
\hline & & & V8 & VT & $\mathrm{R} 3$ & R6 & V8 & $\mathrm{VT}$ & $\mathrm{R} 3$ & $\mathrm{R} 6$ \\
\hline \multirow[t]{12}{*}{2016} & $0-30$ & $\mathrm{~N}_{300}$ & $2.81 \mathrm{a}$ & $19.89 b$ & 19.09ab & $16.45 b$ & 0.99 & 0.93 & 0.93 & 0.93 \\
\hline & & $\mathrm{N}_{225}$ & $3.05 \mathrm{a}$ & $20.78 \mathrm{a}$ & $20.43 \mathrm{a}$ & $17.34 \mathrm{a}$ & 0.99 & 0.92 & 0.92 & 0.91 \\
\hline & & $\mathrm{N}_{150}$ & $1.53 \mathrm{~b}$ & $20.18 b$ & $17.50 \mathrm{~b}$ & $14.41 \mathrm{~b}$ & 0.99 & 0.94 & 0.92 & 0.9 \\
\hline & & $\mathrm{N}_{0}$ & $0.97 \mathrm{c}$ & $15.59 \mathrm{c}$ & $13.19 \mathrm{a}$ & $10.37 \mathrm{c}$ & 1 & 0.89 & 0.91 & 0.9 \\
\hline & $30-60$ & $\mathrm{~N}_{300}$ & $0.03 \mathrm{a}$ & $1.52 b$ & $1.22 \mathrm{~b}$ & $1.23 b c$ & 0.01 & 0.07 & 0.06 & 0.07 \\
\hline & & $\mathrm{N}_{225}$ & $0.03 \mathrm{a}$ & $1.65 \mathrm{a}$ & $1.45 \mathrm{a}$ & $1.45 \mathrm{a}$ & 0.01 & 0.07 & 0.07 & 0.08 \\
\hline & & $\mathrm{N}_{150}$ & $0.01 \mathrm{~b}$ & $1.30 \mathrm{c}$ & $1.26 \mathrm{~b}$ & $1.26 \mathrm{~b}$ & 0.01 & 0.06 & 0.07 & 0.08 \\
\hline & & $\mathrm{N}_{0}$ & $0.00 \mathrm{~b}$ & $1.49 \mathrm{~b}$ & $1.22 \mathrm{~b}$ & $0.99 \mathrm{c}$ & 0 & 0.08 & 0.08 & 0.09 \\
\hline & $60-90$ & $\mathrm{~N}_{300}$ & & $0.03 b$ & $0.13 b$ & $0.08 \mathrm{c}$ & 0 & 0 & 0.01 & 0 \\
\hline & & $\mathrm{N}_{225}$ & & $0.05 b$ & $0.32 \mathrm{a}$ & $0.34 \mathrm{a}$ & 0 & 0 & 0.01 & 0.02 \\
\hline & & $\mathrm{N}_{150}$ & & $0.07 \mathrm{~b}$ & $0.26 \mathrm{a}$ & $0.26 \mathrm{~b}$ & 0 & 0 & 0.01 & 0.02 \\
\hline & & $\mathrm{N}_{0}$ & & $0.52 \mathrm{a}$ & $0.12 b$ & $0.12 \mathrm{c}$ & 0 & 0.03 & 0.01 & 0.01 \\
\hline \multirow[t]{12}{*}{2017} & $0-30$ & $\mathrm{~N}_{300}$ & $3.06 \mathrm{~b}$ & $22.09 \mathrm{a}$ & 19.90ab & $17.33 b$ & 0.96 & 0.93 & 0.93 & 0.92 \\
\hline & & $\mathrm{N}_{225}$ & $4.67 \mathrm{a}$ & $22.99 a$ & $21.90 \mathrm{a}$ & $18.80 \mathrm{a}$ & 0.97 & 0.93 & 0.92 & 0.91 \\
\hline & & $\mathrm{N}_{150}$ & $2.03 \mathrm{c}$ & $21.99 a$ & $19.42 b$ & $15.81 \mathrm{~b}$ & 0.98 & 0.94 & 0.91 & 0.9 \\
\hline & & $\mathrm{N}_{0}$ & $1.36 \mathrm{c}$ & $15.32 b$ & $14.20 \mathrm{c}$ & $11.11 \mathrm{c}$ & 1 & 0.88 & 0.9 & 0.89 \\
\hline & $30-60$ & $\mathrm{~N}_{300}$ & $0.12 \mathrm{a}$ & $1.52 \mathrm{~b}$ & $1.32 \mathrm{c}$ & $1.24 \mathrm{c}$ & 0.04 & 0.06 & 0.06 & 0.07 \\
\hline & & $\mathrm{N}_{225}$ & $0.14 \mathrm{a}$ & $1.65 \mathrm{a}$ & $1.61 \mathrm{a}$ & $1.53 \mathrm{a}$ & 0.03 & 0.07 & 0.07 & 0.07 \\
\hline & & $\mathrm{N}_{150}$ & $0.03 b$ & $1.30 \mathrm{c}$ & $1.48 \mathrm{~b}$ & $1.42 \mathrm{~b}$ & 0.02 & 0.06 & 0.07 & 0.08 \\
\hline & & $\mathrm{N}_{0}$ & $0.01 \mathrm{~b}$ & $1.49 \mathrm{~b}$ & $1.36 \mathrm{c}$ & $1.19 \mathrm{c}$ & 0 & 0.09 & 0.09 & 0.1 \\
\hline & $60-90$ & $\mathrm{~N}_{300}$ & & $0.03 b$ & $0.21 \mathrm{c}$ & $0.19 b$ & 0 & 0 & 0.01 & 0.01 \\
\hline & & $\mathrm{N}_{225}$ & & $0.05 b$ & $0.40 \mathrm{a}$ & $0.41 \mathrm{a}$ & 0 & 0 & 0.02 & 0.02 \\
\hline & & $\mathrm{N}_{150}$ & & $0.07 \mathrm{~b}$ & $0.34 b$ & $0.33 b$ & 0 & 0 & 0.02 & 0.02 \\
\hline & $60-90$ & $\mathrm{~N}_{0}$ & & $0.65 \mathrm{a}$ & $0.21 \mathrm{c}$ & $0.12 \mathrm{~b}$ & 0 & 0.04 & 0.01 & 0.01 \\
\hline
\end{tabular}




\section{Table 5 (on next page)}

Effect of nitrogen application rates on root volume, root surface and root length density

Means followed by different lowercase letters within each column indicate significantly

different $(p<0.05) . N_{300}, N_{225}, N_{150}$ and $N_{0}$ represent application of nitrogen at a rate of 300 ,

225, 150 and $0 \mathrm{~kg} \mathrm{ha}^{-1}$. 


\begin{tabular}{|c|c|c|c|c|c|c|c|c|c|c|c|c|c|c|}
\hline \multirow[t]{2}{*}{ Year } & \multirow[t]{2}{*}{ Soil layer } & \multirow[t]{2}{*}{ Nitrogen rate } & \multicolumn{4}{|c|}{ Root volume $\left(\mathrm{cm}^{3}\right.$ plant $\left.^{-1}\right)$} & \multicolumn{4}{|c|}{ Root surface $\left(\mathrm{cm}^{2}\right.$ plant $\left.{ }^{-1}\right)$} & \multicolumn{4}{|c|}{ Root length density $\left(\mathrm{mm} \mathrm{cm}^{-3}\right)$} \\
\hline & & & V8 & VT & $\mathrm{R} 3$ & R6 & V8 & VT & $\mathrm{R} 3$ & R6 & V8 & VT & $\mathrm{R} 3$ & R6 \\
\hline \multirow[t]{12}{*}{2016} & $0-30$ & $\mathrm{~N}_{300}$ & $31.2 \mathrm{a}$ & $80.7 \mathrm{ab}$ & $80.7 \mathrm{a}$ & $68.6 \mathrm{~b}$ & $306.19 \mathrm{a}$ & $536.5 b$ & $695.8 \mathrm{~b}$ & $569.3 b$ & $0.86 \mathrm{a}$ & $1.24 \mathrm{~b}$ & $0.82 b$ & $1.52 \mathrm{~b}$ \\
\hline & & $\mathrm{N}_{225}$ & $37.7 \mathrm{a}$ & $91.2 \mathrm{a}$ & $89.9 \mathrm{a}$ & $76.6 \mathrm{a}$ & $339.78 \mathrm{a}$ & $611.6 \mathrm{a}$ & $744.9 \mathrm{a}$ & $639.5 \mathrm{a}$ & $0.98 \mathrm{a}$ & $1.54 \mathrm{a}$ & $2.30 \mathrm{a}$ & $1.78 \mathrm{a}$ \\
\hline & & $\mathrm{N}_{150}$ & $17.3 b$ & $86.8 \mathrm{~b}$ & $64.0 \mathrm{~b}$ & $52.4 \mathrm{c}$ & $167.56 \mathrm{~b}$ & $652.4 \mathrm{a}$ & $563.5 \mathrm{c}$ & $472.6 \mathrm{c}$ & $0.50 \mathrm{~b}$ & $1.23 \mathrm{~b}$ & $1.54 \mathrm{c}$ & $1.11 \mathrm{c}$ \\
\hline & & $\mathrm{N}_{0}$ & $10.7 \mathrm{c}$ & $54.0 \mathrm{c}$ & $31.7 \mathrm{c}$ & $26.9 \mathrm{~d}$ & $132.53 \mathrm{c}$ & $405.1 \mathrm{a}$ & $281.8 \mathrm{~d}$ & $228.5 \mathrm{~d}$ & $0.40 \mathrm{~b}$ & $0.90 \mathrm{c}$ & $0.70 \mathrm{~d}$ & $0.53 \mathrm{~d}$ \\
\hline & $30-60$ & $\mathrm{~N}_{300}$ & $1.9 \mathrm{a}$ & $6.7 \mathrm{~b}$ & $6.2 \mathrm{a}$ & $2.9 \mathrm{~b}$ & $10.53 \mathrm{a}$ & $101.4 \mathrm{~b}$ & $73.9 \mathrm{~b}$ & $51.1 \mathrm{~b}$ & $0.05 \mathrm{a}$ & $0.34 \mathrm{bc}$ & $0.48 \mathrm{a}$ & $0.18 b$ \\
\hline & & $\mathrm{N}_{225}$ & $0.8 \mathrm{~b}$ & $9.0 \mathrm{a}$ & $6.7 \mathrm{a}$ & $5.5 \mathrm{a}$ & $8.94 a$ & $117.4 \mathrm{a}$ & $138.0 \mathrm{a}$ & $100.2 \mathrm{a}$ & $0.03 \mathrm{a}$ & $0.39 \mathrm{~b}$ & $0.54 \mathrm{a}$ & $0.4 \mathrm{a}$ \\
\hline & & $\mathrm{N}_{150}$ & $0.1 \mathrm{c}$ & $4.2 \mathrm{c}$ & $3.3 \mathrm{~b}$ & $2.6 \mathrm{~b}$ & $0.97 \mathrm{~b}$ & $88.5 b$ & $90.8 b$ & $66.5 b$ & $0.003 b$ & $0.31 \mathrm{c}$ & $0.44 \mathrm{~b}$ & $0.35 \mathrm{a}$ \\
\hline & & $\mathrm{N}_{0}$ & $0.06 \mathrm{c}$ & $7.1 b$ & $2.9 \mathrm{~b}$ & $1.9 \mathrm{c}$ & $0.17 \mathrm{c}$ & $112.5 \mathrm{a}$ & $14.7 \mathrm{c}$ & $36.5 \mathrm{c}$ & $0.000 \mathrm{~b}$ & $0.46 \mathrm{a}$ & $0.22 \mathrm{c}$ & $0.13 b$ \\
\hline & $60-90$ & $\mathrm{~N}_{300}$ & & $1.1 \mathrm{~b}$ & $2.2 \mathrm{~b}$ & $0.9 \mathrm{c}$ & & $11.1 \mathrm{c}$ & $44.1 \mathrm{c}$ & $26.2 \mathrm{c}$ & & $0.01 \mathrm{c}$ & $0.19 \mathrm{c}$ & $0.07 \mathrm{~b}$ \\
\hline & & $\mathrm{N}_{225}$ & & $3.2 \mathrm{a}$ & $5.2 \mathrm{a}$ & $3.9 \mathrm{a}$ & & $37.4 \mathrm{~b}$ & $118.0 \mathrm{a}$ & $87.9 \mathrm{a}$ & & $0.17 \mathrm{~b}$ & $0.39 a$ & $0.24 \mathrm{a}$ \\
\hline & & $\mathrm{N}_{150}$ & & $1.5 \mathrm{~b}$ & $3.1 \mathrm{~b}$ & $2.6 \mathrm{~b}$ & & $26.1 \mathrm{~b}$ & $91.0 \mathrm{~b}$ & $72.1 \mathrm{~b}$ & & $0.07 \mathrm{c}$ & $0.25 b$ & $0.21 \mathrm{a}$ \\
\hline & & $\mathrm{N}_{0}$ & & $4.6 \mathrm{a}$ & $2.0 \mathrm{~b}$ & $1.0 \mathrm{c}$ & & $118.0 \mathrm{a}$ & $47.9 \mathrm{c}$ & $31.3 \mathrm{c}$ & & $0.35 \mathrm{a}$ & $0.12 \mathrm{c}$ & $0.09 \mathrm{~b}$ \\
\hline \multirow[t]{12}{*}{2017} & $0-30$ & $\mathrm{~N}_{300}$ & $36.8 \mathrm{a}$ & $92.3 b$ & $85.6 \mathrm{~b}$ & $71.6 \mathrm{~b}$ & $428.83 b$ & $624.4 \mathrm{~b}$ & $726.8 \mathrm{a}$ & $611.8 \mathrm{~b}$ & $1.08 \mathrm{~b}$ & $1.37 \mathrm{~b}$ & $1.77 \mathrm{~b}$ & $1.29 b$ \\
\hline & & $\mathrm{N}_{225}$ & $42.9 \mathrm{a}$ & $112.9 \mathrm{a}$ & $103.8 \mathrm{a}$ & $94.3 \mathrm{a}$ & $520.53 a$ & $683.4 \mathrm{a}$ & $779.8 \mathrm{a}$ & $690.1 \mathrm{a}$ & $1.12 \mathrm{a}$ & $1.74 \mathrm{a}$ & $3.05 \mathrm{a}$ & $2.67 \mathrm{a}$ \\
\hline & & $\mathrm{N}_{150}$ & $21.2 \mathrm{~b}$ & $100.4 \mathrm{a}$ & $73.9 b$ & $63.5 \mathrm{~b}$ & $248.31 \mathrm{c}$ & $690.1 \mathrm{a}$ & $609.6 \mathrm{~b}$ & $487.3 \mathrm{c}$ & $0.56 \mathrm{c}$ & $1.43 \mathrm{~b}$ & $1.92 \mathrm{~b}$ & $1.54 \mathrm{~b}$ \\
\hline & & $\mathrm{N}_{0}$ & $11.8 \mathrm{c}$ & $58.4 \mathrm{c}$ & $38.4 \mathrm{c}$ & $32.6 \mathrm{c}$ & $166.37 \mathrm{~d}$ & $560.2 \mathrm{c}$ & $345.4 \mathrm{c}$ & $286.7 \mathrm{~d}$ & $0.52 \mathrm{~d}$ & $1.00 \mathrm{c}$ & $0.97 \mathrm{c}$ & $0.58 \mathrm{c}$ \\
\hline & $30-60$ & $\mathrm{~N}_{300}$ & $2.7 \mathrm{a}$ & $8.3 b$ & $7.2 \mathrm{~b}$ & $3.3 b$ & $11.37 \mathrm{a}$ & $115.7 \mathrm{a}$ & $100.0 \mathrm{~b}$ & $64.2 \mathrm{c}$ & $0.05 \mathrm{a}$ & $0.49 \mathrm{~b}$ & $0.57 \mathrm{a}$ & $0.33 b$ \\
\hline & & $\mathrm{N}_{225}$ & $1.2 \mathrm{~b}$ & $11.0 \mathrm{a}$ & $8.4 \mathrm{a}$ & $6.6 \mathrm{a}$ & $14.15 \mathrm{a}$ & $133.0 \mathrm{~b}$ & $168.5 \mathrm{a}$ & $146.1 \mathrm{a}$ & $0.06 \mathrm{a}$ & $0.53 \mathrm{a}$ & $0.60 \mathrm{a}$ & $0.52 \mathrm{a}$ \\
\hline & & $\mathrm{N}_{150}$ & $0.4 \mathrm{c}$ & $5.5 \mathrm{c}$ & $4.4 \mathrm{bc}$ & $3.4 \mathrm{~b}$ & $1.91 \mathrm{~b}$ & $110.4 \mathrm{a}$ & $110.2 \mathrm{~b}$ & $96.0 \mathrm{~b}$ & $0.02 \mathrm{~b}$ & $0.44 \mathrm{~b}$ & $0.53 b$ & $0.48 \mathrm{a}$ \\
\hline & & $\mathrm{N}_{0}$ & $0.3 \mathrm{c}$ & $8.5 b$ & $3.8 \mathrm{c}$ & $2.6 \mathrm{~b}$ & $0.34 \mathrm{c}$ & $145.5 b$ & $29.0 \mathrm{c}$ & $54.9 \mathrm{c}$ & $0.03 \mathrm{~b}$ & $0.58 \mathrm{a}$ & $0.33 \mathrm{c}$ & $0.25 \mathrm{c}$ \\
\hline & $60-90$ & $\mathrm{~N}_{300}$ & & $1.4 \mathrm{~b}$ & $3.2 \mathrm{~b}$ & $1.1 \mathrm{c}$ & & $29.3 d$ & $76.2 b$ & $49.1 \mathrm{c}$ & & $0.09 \mathrm{c}$ & $0.29 \mathrm{c}$ & $0.10 b c$ \\
\hline & & $\mathrm{N}_{225}$ & & $4.8 \mathrm{a}$ & $6.3 \mathrm{a}$ & $4.3 \mathrm{a}$ & & $84.3 \mathrm{~b}$ & $145.7 \mathrm{a}$ & $126.3 \mathrm{a}$ & & $0.30 \mathrm{~b}$ & $0.47 \mathrm{a}$ & $0.31 \mathrm{a}$ \\
\hline & & $\mathrm{N}_{150}$ & & $2.3 \mathrm{~b}$ & $3.7 \mathrm{~b}$ & $3.1 \mathrm{~b}$ & & $46.2 \mathrm{c}$ & $101.1 \mathrm{~b}$ & $87.9 \mathrm{~b}$ & & $0.13 \mathrm{c}$ & $0.36 \mathrm{~b}$ & $0.30 \mathrm{~b}$ \\
\hline & & $\mathrm{N}_{0}$ & & $5.5 \mathrm{a}$ & $3.0 \mathrm{~b}$ & $2.0 \mathrm{c}$ & & $145.1 \mathrm{a}$ & $60.2 \mathrm{c}$ & $36.3 \mathrm{c}$ & & $0.44 \mathrm{a}$ & $0.20 \mathrm{c}$ & $0.10 \mathrm{c}$ \\
\hline
\end{tabular}

1 